\title{
Nerve Ultrasound as Helpful Tool in Polyneuropathies
}

\author{
Magdalena Kramer ${ }^{1}$, Alexander Grimm ${ }^{1, *}$, Natalie Winter ${ }^{1}$, Marc Dörner ${ }^{1,2} \mathbb{D}$, Kathrin Grundmann-Hauser ${ }^{3}$, \\ Jan-Hendrik Stahl ${ }^{1}$, Julia Wittlinger ${ }^{1}$, Josua Kegele ${ }^{1}$, Cornelius Kronlage ${ }^{1}$ and Sophia Willikens ${ }^{1}$
}

1 Department of Neurology and Epileptology, Tübingen University Hospital and Hertie Institute for Clinical Brain Research, Eberhard Karls University Tübingen, 72076 Tübingen, Germany; magdalena.kramer@med.uni-tuebingen.de (M.K.); natalie.winter@med.uni-tuebingen.de (N.W.); marc.doerner@med.uni-tuebingen.de (M.D.); jan-hendrik.stahl@med.uni-tuebingen.de (J.-H.S.); julia.wittlinger@med.uni-tuebingen.de (J.W.); josua.kegele@med.uni-tuebingen.de (J.K.); cornelius.kronlage@med.uni-tuebingen.de (C.K.); sophia.willikens@med.uni-tuebingen.de (S.W.)

2 Department of Forensic Psychiatry, University Hospital of Psychiatry Zurich, University of Zurich, 8008 Zurich, Switzerland

3 Institute of Medical Genetics and Applied Genomics, Tübingen University Hospital, Eberhard Karls University Tübingen, 72076 Tübingen, Germany; kathrin.grundmann@med.uni-tuebingen.de

* Correspondence: alexander.grimm@med.uni-tuebingen.de; Tel.: +49-7071-29-0

check for updates

Citation: Kramer, M.; Grimm, A.; Winter, N.; Dörner, M.;

Grundmann-Hauser, K.; Stahl, J.-H.; Wittlinger, J.; Kegele, J.; Kronlage, C.; Willikens, S. Nerve Ultrasound as Helpful Tool in Polyneuropathies. Diagnostics 2021, 11, 211. https:// doi.org/10.3390/diagnostics11020211

Academic Editor: Rute Santos

Received: 30 December 2020

Accepted: 27 January 2021

Published: 31 January 2021

Publisher's Note: MDPI stays neutral with regard to jurisdictional claims in published maps and institutional affiliations.

\begin{abstract}
Background: Polyneuropathies (PNP) are a broad field of diseases affecting millions of people. While the symptoms presented are mostly similar, underlying causes are abundant. Thus, early identification of treatable causes is often difficult. Besides clinical data and basic laboratory findings, nerve conduction studies are crucial for etiological classification, yet limited. Besides Magnetic Resonance Imaging (MRI), high-resolution nerve ultrasound (HRUS) has become a noninvasive, fast, economic and available tool to help distinguish different types of nerve alterations in neuropathies. Methods: We aim to describe typical ultrasound findings in PNP and patterns of morphological changes in hereditary, immune-mediated, diabetic, metabolic and neurodegenerative PNP. Literature research was performed in PubMed using the terms 'nerve ultrasound', neuromuscular ultrasound, high-resolution nerve ultrasound, peripheral nerves, nerve enlargement, demyelinating, hereditary, polyneuropathies, hypertrophy'. Results: Plenty of studies over the past 20 years investigated the value of nerve ultrasound in different neuropathies. Next to nerve enlargement, patterns of nerve enlargement, echointensity, vascularization and elastography have been evaluated for diagnostic terms. Furthermore, different scores have been developed to distinguish different etiologies of PNP. Conclusions: Where morphological alterations of the nerves reflect underlying pathologies, early nerve ultrasound might enable a timely start of available treatment and also facilitate follow up of therapy success.
\end{abstract}

Keywords: high-resolution nerve ultrasound; peripheral nerve imaging; demyelinating polyneuropathies; hereditary polyneuropathies

\section{Introduction}

Polyneuropathies are among the most frequent neurological disorders and cause significant morbidity and use of resources. Finding the cause of neuropathic deficits still remains a challenge in daily clinical routine. Although technical tools have improved and nerve conduction studies, skin and nerve biopsy, next generation sequencing, cerebrospinal fluid (CSF) analysis or antibody testing are established methods, the cause of PNP remains unclear in up to one third of patients. Imaging tools such as MRI of the roots and nerves could contribute to the diagnosis of immune-mediated neuropathies, hereditary transthyretin (TTR) associated systemic amyloidosis and others in the recent past [1-3]. However, their use is still limited to specialized centers. In contrast, ultrasound is a widely distributed tool, which is able to visualize nerves and roots with high resolution and accuracy. A growing number of studies has been published in the last decade concerning 
ultrasound findings in polyneuropathies [4,5]. The aim of this review is to give an overview and to propose an algorithm for examination of patients with suspected PNP including nerve ultrasound and nerve conduction studies.

\section{Ultrasound Parameters in Neuropathies}

Several aspects can be visualized and measured by ultrasound [6,7]. Before scanning the nerves, the examiner must be aware of the normal nerve appearance, especially in regard to nerve size, nerve and fascicle anatomy, echointensity, vascularity, elastography and surrounding tissue morphology (example is given in Figure 1). For differentiation of PNP the following parameters have been proven to be most useful: (1) The most simple feature is the enlargement of cross-sectional area (CSA), which can be seen either focally restricted (one short nerve segment), regionally (larger nerve segments) or diffusely (the whole nerve) within one nerve (unifocal), several nerves (multifocal) or all nerves and roots (generalized) (Figure 2). Further, nerve enlargement can exhibit certain predominance (e.g., proximal enlargement including the roots, the plexus and the proximal segments of the nerves). (2) CSA enlargement is typically more often seen in demyelinating neuropathies than in axonal types. Next to CSA enlargement of the whole nerve, some PNP reveal a fascicular enlargement pattern, in which one or more fascicles can be involved. In patients with multifocal motor neuropathy (MMN) single fascicles are enlarged next to normal sized fascicles (Figure 3D) [8,9]. Fascicle enlargement in PNP can also be regional (some fascicles enlarged in some nerves, sparing other nerves), differential (sparing some fascicles, but affecting all nerves) or generalized (affecting all fascicles and all nerves) (3). Depending on the number and size of affected fascicles, the CSA of the whole nerve can be enlarged as well. However, fascicle visualization and thus size interpretation must be handled with caution because the resolution and therefore the probe frequency plays an important role $[8,10]$. Recently, the focus has been further set on nerve echointensity [11-14]. The echo signal of the healthy nerve contains the hyperechoic area (i.e., the epineurium, the perineurium) and hypoechoic area (i.e., the nerve bundles). Padua and colleagues already described echointensity changes in some patients with chronic inflammatory demyelinating polyneuropathies (CIDP) [11]. Similar findings have been made by Haertig et al. and Fisse et al. [12,13]. Taken together, next to nerve enlargement, nerves can be hyperechoic (particularly fascicles due to scar tissue, fibrosis or axonal damage) or hypoechoic (maybe provoked by inflammation or edema). The qualitative description of the echo signal might be more suitable for daily routine; however, the quantitative analysis by software tools (grey scale analysis and fraction of black) is increasingly used as a more common method. (4) Concerning nerve vascularity, nerve elastography and the perinerval tissue, new insights have been published $[15,16]$, but its role in PNP still remains unclear and thus description of these methods will not be discussed at this point. 

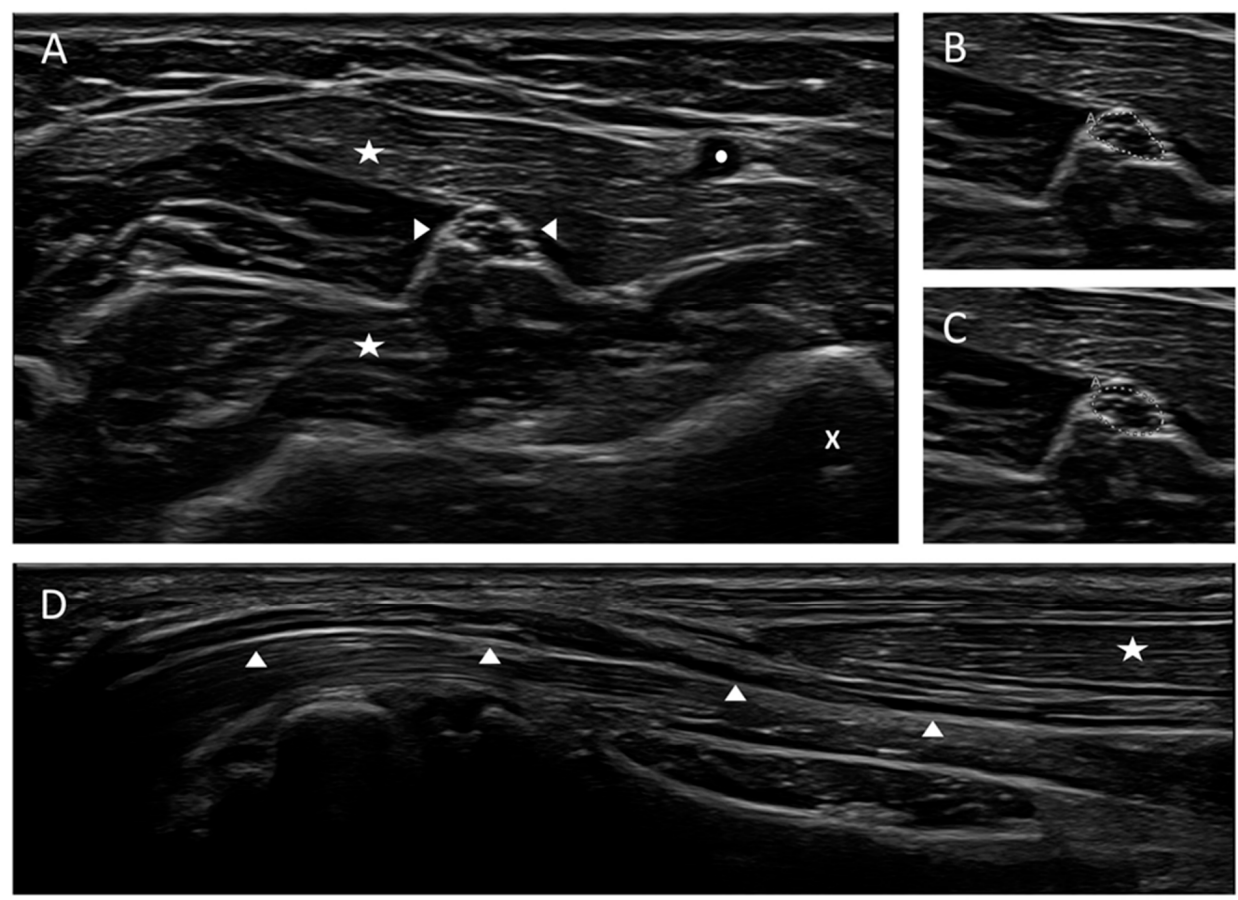

Figure 1. Cross-sectional and longitudinal view of a normal median nerve at forearm level. (A) Cross-sectional view of the median nerve. The nerve appearance is honey-comb-like with hypoechoic fascicles and hyperechoic epi- and perineurium. $(\mathbf{B}, \mathbf{C})$ Measurement techniques of the cross-sectional area (CSA) using the free-hand (B, upper picture) or ellipse function (C, lower picture) of the ultrasound device, CSA $5 \mathrm{~mm}^{2}$. (D) Longitudinal view of the median nerve in panoramic view. Left side of the picture: entrance into carpal tunnel. Arrow heads are marking the nerve, asterisks the superficial and flexor digitorum muscles, the circle the radial artery and the $\mathrm{x}$ the radial bone, " $\mathrm{A}$ " in pictures $\mathrm{B}$ and $\mathrm{C}$ means "area".
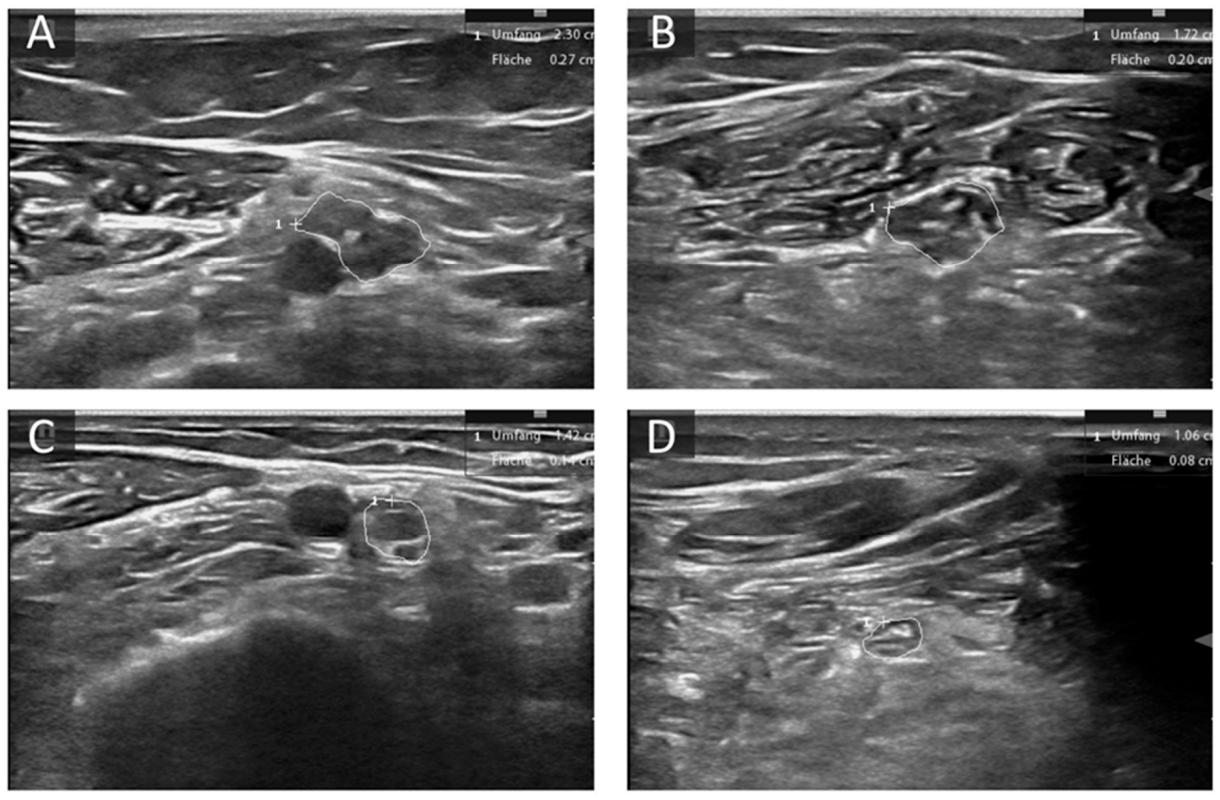

Figure 2. Examples of altered nerve morphology in hereditary neuropathies. (A,B) Cross-sectional view of the median nerve at the upper arm (A) and forearm (B) of a patient with Charcot Marie Tooth (CMT) 1A. CSA is enlarged (27 mm ${ }^{2}$ upper $\mathrm{arm}, 20 \mathrm{~mm}^{2}$ forearm) and the fascicles are hypoechoic. (C,D) Cross-sectional view of the median nerve at the upper arm (C) and forearm (D) of a patient with transthyretin related amyloidosis (ATTR). CSA is mildly enlarged at the upper $\operatorname{arm}\left(14 \mathrm{~mm}^{2}\right)$ and normal at forearm level $\left(8 \mathrm{~mm}^{2}\right)$. The area enclosed by circles depicts CSA of the described nerve section, "+" shows curser position, " 1 " the count of measured areae. 

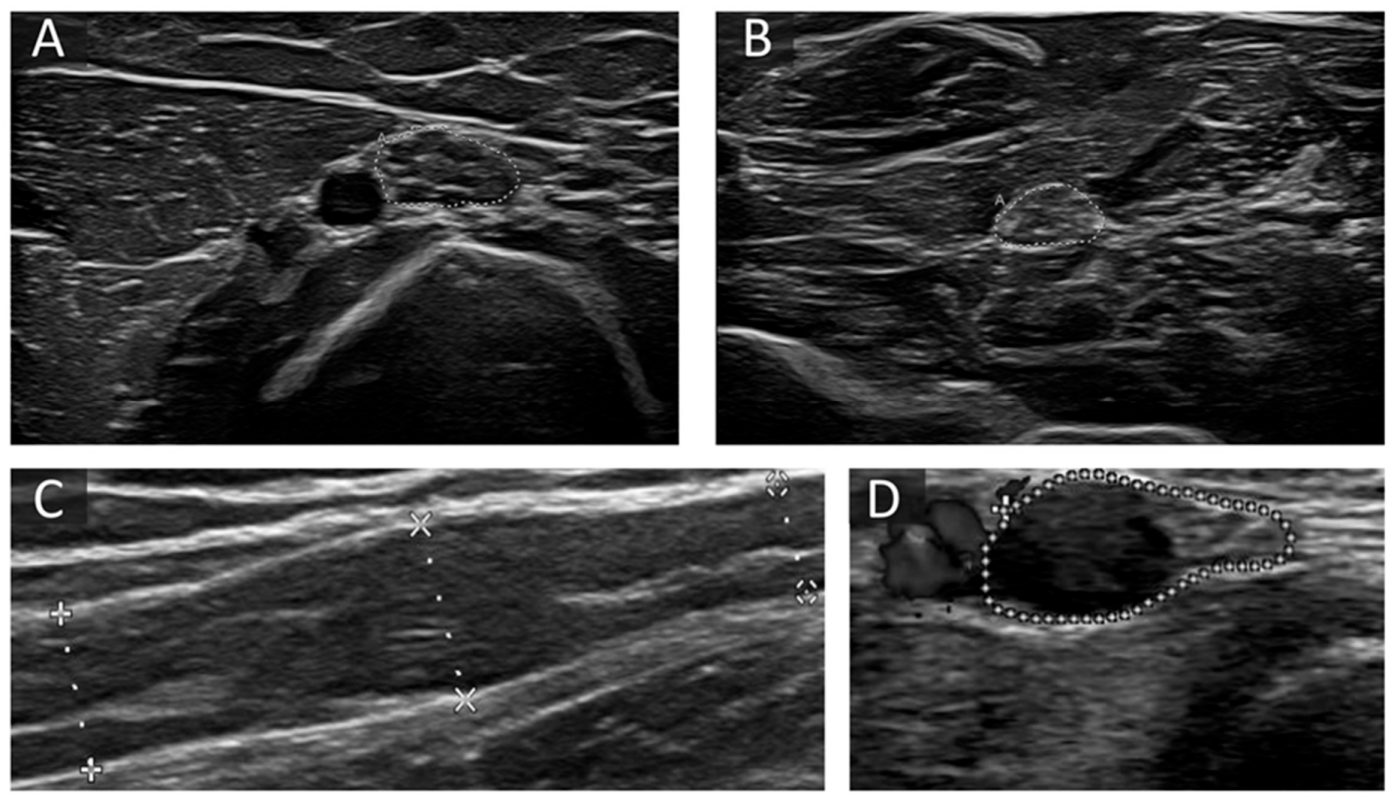

Figure 3. Examples of altered nerve morphology in immune-mediated neuropathies. (A,B) Cross-sectional view of the median nerve at the upper $\operatorname{arm}\left(30 \mathrm{~mm}^{2}\right)(\mathbf{A})$ and forearm $\left(17 \mathrm{~mm}^{2}\right)(\mathbf{B})$ in a patient with chronic inflammatory demyelinating polyneuropathies (CIDP). CSA is predominantly enlarged at proximal sites, and fascicles are iso- and hyperechoic. (C) shows a long-axis view of a segmentally enlarged median nerve at the upper arm in a patient with Lewis-Sumner Syndrome (LSS). (D) The short-axis view shows an ulnar nerve at the forearm next to the ulnar artery with one very large fascicle with hypoechoic signal next to preserved fascicles in a patient with multifocal motor neuropathy (MMN). The area enclosed by the discontinuous points in picture A, B and D depict CSA, in picture C diameter of the described nerve section. "A" in pictures B and D means "area".

\section{General Aspects and Examination Protocols}

So far, reference data for CSA in adults and children older than two years for most of the larger peripheral nerves have been published by many groups [17-25]. However, if values from literature are used, ethnic differences have to be kept in mind, i.e., CSA tend to be smaller in the Asian population $[18,26]$. The authors suggest obtaining your own reference values analogous to recommendations for nerve conduction studies. Reference data for nerve echointensity are sparse and only a few studies have published quantitative analysis values [14]. In daily clinical routine, a qualitative analysis in comparison to surrounding tissue, for example vessels, muscles, fat filled flat tunnels and fascia, should be used.

Another important point is to establish a scanning protocol, which includes the nerve and its measure points. Several analyzing protocols have been published so far [17-25,27]. Unfortunately, common protocols or guidelines (as in nerve conduction studies) do not exist so far [6]. Overall, analysis of all large nerves $\left(>1 \mathrm{~mm}^{2}\right)$ is feasible. We recommend a structured analysis of cervical roots (C5 and C6), vagus, median, ulnar and radial nerve, tibial, fibular and sural nerve and its measurement at predefined measurement points [20]. In cases of symmetric neuropathies, unilateral scans might be suitable, in cases of asymmetric neuropathy, bilateral scans are required. Each nerve should be scanned in its entire course as far as possible, whereas for reproducibility predefined landmarks should be used for measurement (see section scoring systems). To ensure exact data, the measurement of CSA and fascicle area should be carried out strictly within the hyperechoic rim and the echointensity analysis must be performed in predefined gains. The aim of this examination is to define neuropathies with enlarged nerves (hypertrophic neuropathies), and thus to visualize the nerve enlargement pattern as mentioned before. In the following sections we will describe known patterns of distinct neuropathies. 


\section{Hereditary Neuropathies}

The most intriguing nerve enlargement can be found in patients with Charcot Marie Tooth (CMT) type 1 (CMT1) neuropathies, particularly type A [27-38]. Most of these patients (88-100\%) exhibit a generalized nerve enlargement present at all sites with at least one region showing a CSA more than twice of the upper normal limit (Figure 2A,B). Nerve hypertrophy in CMT1 is already visible in children [27,33]. In CMT1B patients, nerves exhibit an enlarged CSA as well, but enlargement is less pronounced in comparison to CMT1A patients [37-39]. Other ultrasound findings in CMT1 types, for example CMT1C, have only rarely been reported regarding nerve size, but in most cases a similar pattern as in CMT1B has been found [32,37-40]. Recently, Castoro and colleagues described the case of a young patient with CMT4J, where a proximal predominant nerve enlargement pattern was seen [41].

In addition, the number of reported patients with a genetically confirmed neuropathy and a superimposed nerve inflammation increases rapidly [42]. In 1982, Peter J. Dyck and his colleagues were one of the first to describe a response to immune modulatory treatments in CMT patients [43]. In these overlap neuropathies a co-occurrence of a GuillianBarre syndrome (GBS)- or CIDP-like disease course in patients with genetically confirmed polyneuropathies was reported. In all described cases, the onset of worsening occurred suddenly after a long period of a stable or slowly progressive disease course. Nerve enlargement seemed to decrease under immune modulatory therapy and symptoms improved, but further studies are needed to evaluate this entity. [44,45]

In contrast to demyelinating CMT1 types, in axonal CMT forms, CMT2, almost no nerve enlargement occurs. Merely, some fascicles can be enlarged, but CSA is broadly documented within reference ranges $[30,34,36]$. On the other hand, patients with X-linked CMT1 (CMT1X), show an intermediate pattern with moderate nerve enlargement, particularly in male patients [36].

Remarkably, the underlying genetic defect and not nerve conduction study (NCS) results (axonal or demyelinating) seems to determine the nerve morphology in CMT, considering that in neurofilament light polypeptide gene (NEFL) or myelin protein zero (MPZ) associated CMT1 or CMT2 similar ultrasound aspects are observed [32].

Finally, hereditary neuropathy with liability to pressure palsies (HNPP), mostly due to peripheral myelin protein 22 (PMP22) deletion, has a pathognomonic pattern of nerve enlargement at entrapment sites (e.g., carpal tunnel, cubital tunnel, fibular tunnel, and supinator loge) with normal nerve segment in between. Entrapment ratios (calculated by CSA at entrapment site divided by CSA at normal sites) are enlarged (e.g., wrist-toforearm ratio), which enables differentiation to other inherited and demyelinating neuropathies [30,31,36,46-50]. Exceptions are sites with known long-lasting compression and consecutive tomaculae in the corresponding position. Straight anamnesis might elucidate the background of enlargement outside classical entrapment sites. Nevertheless, multifocal entrapment syndromes are not specific and can also occur in other neuropathies, like for example hereditary transthyretin related amyloidosis (ATTR) or diabetic neuropathy (DN) [5].

\section{Hereditary Transthyretin Related and Sporadic Amyloidosis}

ATTR is a systemic disorder leading to amyloid fibril deposition with cardiac dysfunction, carpal tunnel syndrome and severe autonomic and sensorimotor polyneuropathy [51]. Meanwhile, three drugs have been established complementing liver transplantation, the only therapy existing so far. These are TTR-stabilizer tafamidis, small interfering ribonucleic acid (RNA) patisiran and antisense oligonucleotide inotersen. As all of them are solely approved for first or second stages of ATTR and rareness of the disease often leads to delayed diagnosis, a good diagnostic tool for early and correct diagnosis is essential [52,53]. Magnetic Resonance (MR) neurography already proved its usefulness in detecting peripheral nerve pathology especially in lower limbs and even prior to the onset of symptoms in genetic variant carriers [2]. Further, this nerve enlargement can also be seen by ul- 
trasound, particularly at entrapment sites (Figure 2C,D) [54]. Podnar et al. found that besides common entrapment sites, a pronounced nerve enlargement in a larger cohort of ATTR patients was also seen in proximal segments and plexus [55], and even of presymptomatic carriers [56]. This finding suggests ultrasound as an important tool to enable early treatment.

In contrast to ATTR, little is known about acquired amyloidosis. One case with amyloid light-chain (AL) amyloidosis is described with severe course and significant nerve enlargement suggesting a correlation between amyloid deposits in the nerves and mentioned enlargement; however, further studies are required [57].

\section{Immune-Mediated Neuropathies}

The role of imaging tools in CIDP, like MR neurography and HRUS, has been widely analyzed [3,11-13,58-70]. All authors describe nerve enlargement, particularly affecting proximal nerve segments and roots, which might facilitate a differentiation from CMT1 (Figure 3A,B). Enlargement can be found in up to $90 \%$ of patients (sensitivities range between 64 and $89 \%$ depending on the used scores and values), however to a very heterogeneous amount, ranging from a focal or regionally restricted to diffuse pattern. Even in patients with NCS not fulfilling the European Federation of Neurological Societies (EFNS) criteria, nerve enlargement can be observed with a high sensitivity, whereas the specificity of this finding is lower than this of NCS [71-75]. It is noteworthy that the amount of nerve enlargement does probably not correlate with disease severity, but with disease duration $[59,64]$. Interestingly, nerve enlargement is reversible in many cases, particularly in those with excellent therapeutic response [12,13,74].

Three distinct classes of nerve enlargement have been described [11,12]: Class 1 with hypoechoic nerve enlargement, Class 2 with hypo- and hyperechoic nerve enlargement and Class 3 with almost no nerve enlargement. Class 1 is the best treatment reactive, whereas Class 3 does respond least to therapy. Reasons might be a more chronic and axonal damage as well as fibrosis in Class 2 and 3. Further data will be needed to prove this suggestion. Additionally, ultrasound of the muscles might be useful as a prognostic marker to further evaluate axonal damage [76]. The role of ultrahigh-frequency ultrasound to detect fascicle affection in CIDP seems promising; however, it must be further proven [77] and the availability of these probes is restricted.

Only few data are available concerning imaging of paranodopathies, but the pattern seems to be similar to that seen in typical CIDP, probably more often affecting cranial nerves $[78,79]$.

Only few reports concerning patients with Lewis-Sumner Syndrome (LSS) or multifocal acquired demyelinating sensory and motor neuropathy (MADSAM) are available [80-86]. Most authors mixed them with other CIDP types, which might hamper the right description of this immune-mediated subtype. Overall, patients with LSS show a similar pattern as those with CIDP, however with a more asymmetric distribution and sometimes enlargement in more distal segments [3]. In some cases, focal enlargement, restricted to one fascicle, can be seen and is correlated with nerve conduction block (Figure 3C) [81]. The enlargement however can be tremendous. Some patients even show enlargement of cranial nerves [84]. Scoring tools including the enlargement pattern, fascicle morphology and echotexture might help to differentiate several immune-mediated and hereditary neuropathies $[87,88]$. Just as suggested in CIDP, nerve enlargement in LSS might disappear or decrease under successful treatment $[89,90]$.

In patients with monoclonal gammopathy of undetermined significance (MGUS) and polyneuropathy, we have to differentiate several subtypes of neuropathies [91]. This is most important as several subtypes implicate distinct therapies [92]. Most patients exhibit an axonal NCS type with distal symmetric polyneuropathy and no nerve enlargement, probably with no immune-mediated pathology [93]. These consequently do not respond well to immunomodulatory treatment. However, if nerve enlargement is found despite axonal neuropathy type in MGUS, immunotherapy might be an option, as shown in two 
cases of M-protein related neuropathies [93]. Furthermore, we can find CIDP-like types in all immunoglobulin-mediated variants (MGUS-CIDP). Their pattern appears the same as in classical CIDP. Importantly, in immunoglobulin M (IgM)-MGUS, patients with positive anti-myelin associated glycoprotein (MAG) antibodies show a poor response to treatment with steroids and intravenous immunoglobulins (IVIG). Here, anti-CD20 antibodies or tyrosine kinase inhibitors seem to be more effective. In anti-MAG neuropathy, nerve enlargement pattern can be similar to that in LSS and CIDP, for example also affecting the roots, while NCS data exhibit a distal predominant pattern, but can also just be mild [93,94]. Furthermore, small sensory distal branches can be affected [95].

So far, less is known about POEMS (polyneuropathy, organomegaly, endocrinopathy, monoclonal protein, skin changes) patients, who exhibit demyelinating NCS with uniform pattern and, as described so far, enlarged CSA especially in entrapment sites or slightly enlarged nerves as compared to healthy controls [96,97]. This enlargement might decrease with successful treatment.

Another immune-mediated neuropathy affecting several pure motor nerves in one or more limbs with mostly asymmetric onset is the multifocal motor neuropathy (MMN [98]. In NCS, conduction blocks are the main finding, however in very proximal segments this examination might be difficult [99]. Often present in this case are GM1-IgM antibodies with sensitivity of up to $70 \%$, but low specificity [100]. Treatment with immunoglobulins is the only one effective so far, thus, early differentiation from clinically similar diseases like amyotrophic lateral sclerosis (ALS), inclusion body myositis or pure motor CIDP is crucial. Nerve enlargement was first described by Beekman et al. in MMN [101], followed by several other authors [9,102-105]. In MMN, nerve enlargement is much more regionally or focally limited than in LSS and CIDP, often only affecting one or few fascicles (Figure 3D). Herein, one can often detect electrophysiological conduction blocks, but there is not always a correlation to fascicular enlargement [9]. Fascicle enlargement can disappear with treatment with intravenous or subcutaneous immunoglobulins. Distribution is mostly asymmetric, showing side-to-side differences and greater intra-nerve variability than CIDP patients [106]. Sensory nerves are spared in MMN, in NCS as well as in ultrasound [102]. By finding multifocal nerve enlargement, differentiation from ALS might be facilitated. However, slight nerve enlargement might also be seen in the beginning stage and probably in the inflammatory type of ALS [107], even though in contrast, MMN nerves in ALS develop atrophy during the course of disease [108]. According to literature, sensitivity and specificity of ultrasound ranges between $88-100 \%$ and $93-100 \%$.

The acute variant of an immune-mediated neuropathy, GBS, is mostly preceded by an infectious gastrointestinal or pulmonary disease, most frequently by Campylobacter jejuni infection. Other associations with Zika, Cytomegaly and severe acute respiratory syndrome coronavirus type 2 (SARS-CoV-2) infection have been described [109-111]. Clinical symptoms are distally arising sensory and predominantly motor symptoms leading to tetraparesis including autonomic dysregulation and cranial nerve palsies. Several clinical variants and atypical cases exist. CSF typically exhibits cytalbuminic dissociation, however often not before week two after clinical onset. NCS data can be inevident in the first days, but are later observed on proximal pathologies or multifocal A-waves. Most patients exhibit prominent nerve root and vagus nerve enlargement in ultrasound already in the first days of symptoms [112-114]. Sensitivity, specificity, and positive predictive values are $>85 \%$ in literature. Root enlargement resembles radiculitis in GBS, distal segments are not predominantly swollen. Vagus nerve enlargement seems to correlate with autonomic dysregulation and thus might promote the risk of stratification in the future [112]. These findings can occur in axonal and demyelinating types [114-116]. Recently, nerve enlargement has also been described in Post-SARS-CoV-2-GBS [117]. Importantly, nerve root enlargement disappears or might decrease in most cases, equally in adults and in children, after successful treatment within three months. Early decrease of nerve enlargement in GBS under therapy is opposed to patients with CIDP, which facilitates differentiation of both entities [118-120]. In the beginning a differentiation of GBS and acute-onset CIDP 
might be possible by the more prominent swelling of peripheral sensorimotor nerves in the latter case. Further sensory nerve swelling also seems to be pathognomonic for chronic immune-mediated neuropathies [120].

The Miller Fisher syndrome (MFS), presenting with ataxia, areflexia and ophthalmoplegia, is a variant of GBS with antiGQ1b IgG antibodies, often presenting as an overlap syndrome with MFS and GBS symptoms [109], also showing enlargement of the roots and cranial nerves [116].

\section{Diabetic Neuropathies}

Although DN are a large and important part of all neuropathies worldwide, literature concerning ultrasound in this entity is not rich. Some authors suggest that DN does not cause nerve enlargement, particularly the classical distal-symmetric axonal type [5,121]. However, this is consistent with the finding that we see nerve enlargement in demyelinating neuropathies rather than in the axonal forms; still, even in the mixed axonal and demyelinating forms, there was no difference between DN and controls [121]. Exceptions are the entrapment areae, which often exhibit nerve enlargement (e.g., tarsal tunnel, carpal tunnel) [122]. Still, some other authors found that nerve size might increase in DN to some amount compared to controls, depending on severity and in one study even correlating with Hemoglobin A1c (HbA1c) independent of the presence of a neuropathy [122-127]. Still, with exact regard on the published data, nerve enlargement in DN does not exceed upper reference values. In contrast, the vagus nerve was found to be smaller and atrophic in patients with diabetes [128], maybe explaining autonomic dysregulation in DN. The influence of several subtypes and its distinct NCS pattern (e.g., axonal or demyelinating), as well as therapeutic approaches are so far missing in ultrasound studies. Thus, interpretation of ultrasound findings in diabetes patients has to be done with care. Significant and multifocal nerve enlargement outside of entrapment sites in a patient with diabetes must raise attention for a second reason for neuropathy, for example inflammation or underlying hereditary neuropathy. Further, there have been recent descriptions of increased nerve stiffness, as evaluated by shear wave elastography [16]; however, the method has to be confirmed in larger studies. With regard to its importance, further studies clearly differentiating types of diabetes, therapeutic concepts and neuropathy forms are required to the authors' opinion.

\section{Other Axonal Neuropathies}

Until now, ultrasound patterns for axonal neuropathies have mostly been described as for subgroups of large cohorts, not differentiating between toxic, metabolic, idiopathic or inherited axonal neuropathies $[58,129,130]$. Overall spoken, nerve enlargement is not existent in most axonal neuropathies. Exceptions in acquired immune-mediated types have been described, such as sarcoidosis [129], although here nerve enlargement did not correlate with clinical function or electrophysiological findings. Furthermore, similar results were found for vasculitic neuropathies [130-133] as well as infectious neuritis (e.g., borreliosis, hepatitis E $[134,135])$, in which focal nerve enlargement might be seen. Besides the exceptions mentioned above, nerve enlargement is particularly seen in clinically affected nerves. Notably, distal sensory segments can be significantly involved, which might serve as a localization for further diagnostics, like for example nerve biopsy [132]. Sonographic differentiation from demyelinating immune-mediated neuropathies is possible as proximal parts such as roots and plexus are mostly spared in vasculitis and enlargement is only slight to moderate with restricted expansion [136]. Data regarding nerve alterations in chemotherapy induced neuropathies are inconsistent; however, most authors state no or only focal nerve enlargement in those patients. In patients with taxane treatment though, smaller CSA values of the sural nerve were found [137], whereas in oxaliplatine treated patients a slight increase of the tibial and peroneal nerve was reported [138]. This difference might be due to the distinct pathology (neuropathy vs. neuronopathy), still, larger studies are mandatory to confirm these data. Neurodegenerative axonal neuropathies might exhibit 
small nerve CSA, as shown for progressive ataxia syndromes with neuropathy such as Cerebellar ataxia neuropathy vestibular areflexia syndrome (CANVAS) and spinocerebellar ataxia type 2 [139].

Another entity of neuropathies, which has recently been more and more diagnosed and though is not entirely understood, is the small fiber neuropathy (SFN). SFN often presents with neuropathic pain and numbness while revealing normal NCS. The use of nerve ultrasound in SFN is currently under investigation.

\section{Neurolymphomatosis and GRAFT Versus Host Diseases}

Neoplastic affection of the peripheral nerve system (PNS) in lymphoma is a rare manifestation called neurolymphomatosis [140] and arises as mono- or multiplex polyneuropathy. Tremendous nerve enlargement seen by ultrasound might help to detect this pathology, which finally must be confirmed by biopsy or positron emission tomography (PET)-imaging [141].

Graft versus host disease (GvHD) after allogenic marrow transplantation mostly affects the skin and the gastrointestinal system. However, neuromuscular involvement can be an issue [142]. If the PNS is involved, courses exhibit GBS- or CIDP-like features. NCS data and, if demyelination is found, nerve ultrasound can help to diagnose GvHD neuropathy. However, diagnosis might also be hampered by preexisting toxic axonal neuropathy due to chemotherapy. Here, nerve enlargement, comparable to CIDP or GBS findings, might help to identify PNS-GvHD [143,144]. Treatment options are comparable to those used for the autoimmune mediated neuropathies but must also be in concordance with treatment concerning the transplant.

\section{Storage Diseases}

Growing data are available concerning rare storage diseases, for example metachromatic leucodystrophies, adrenoleucodystrophies, xantochromatosis or glucocerebrosidosis $[27,145-147]$. Until now, even though only limited data exist, most of the patients with storage diseases show nerve enlargement, possibly due to accumulation of intermediate metabolites within the myelin sheets, according to demyelinating NCS in most of these cases. Two examples of enlarged nerves in these rare neuropathies are given in Figure 4. If patients with central nervous deficits and polyneuropathy show coexisting nerve enlargement in nerve ultrasound, testing for rare lysosomal storage diseases should be initiated. 

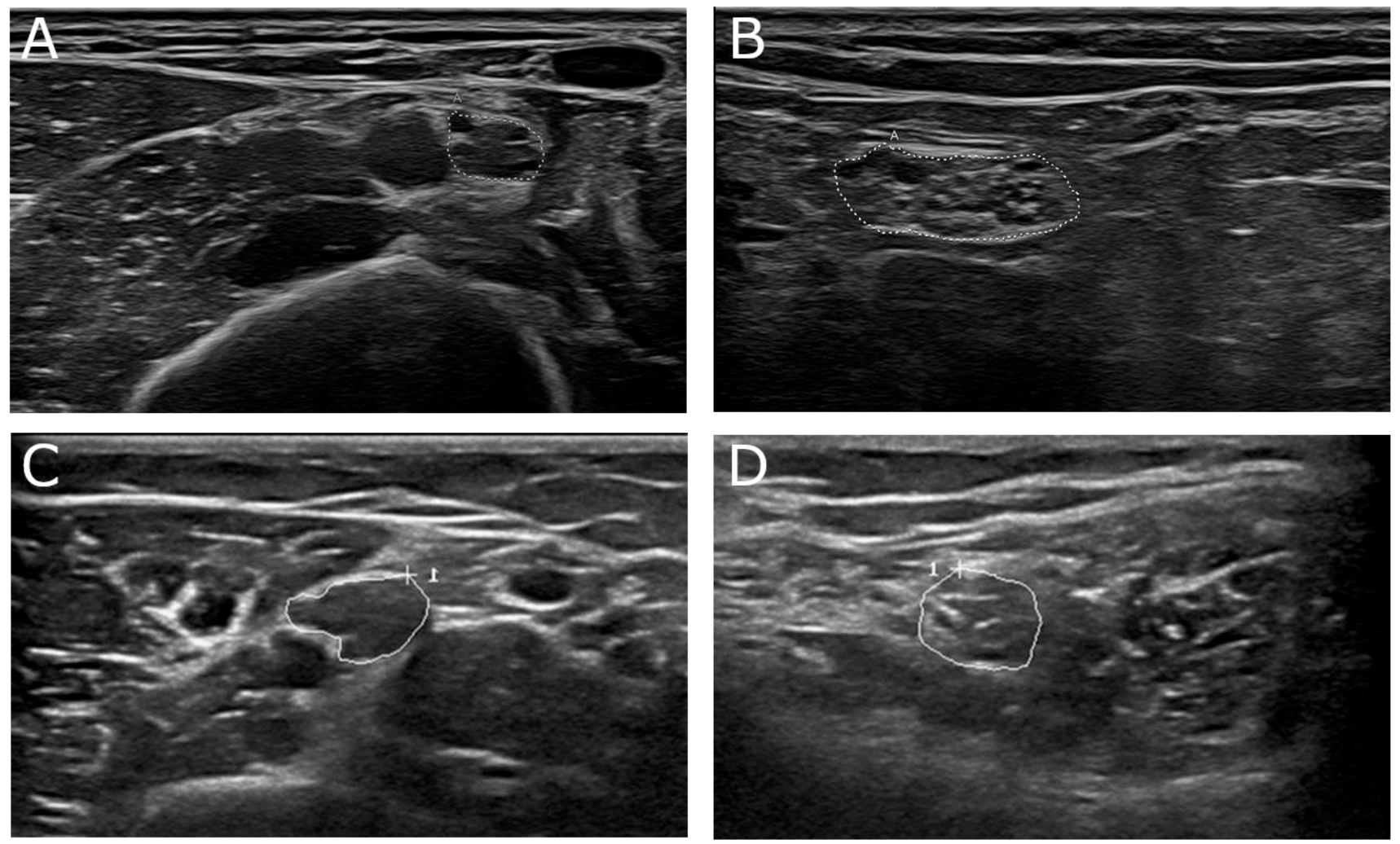

Figure 4. (A,B) 68-year-old male patient with genetically proven adrenomyeloneuropathy, an adult form of adrenoleukodystrophy. Nerve conduction studies showed a demyelinating damage pattern. In nerve ultrasound focal nerve enlargement was detected with a UPSS of 7 points. (A) Median nerve at upper arm segment (cross-sectional area (CSA) $15 \mathrm{~mm}^{2}$, normal value $12 \mathrm{~mm}^{2}$ ). (B) Tibial nerve at popliteal fossa (CSA $51 \mathrm{~mm}^{2}$, normal value $33 \mathrm{~mm}^{2}$ ). (C,D) 16-year-old female patient with juvenile form of metachromatic leukodystrophy. Focal nerve enlargement was seen in median nerve (C, CSA $\left.20 \mathrm{~mm}^{2}\right)$ at proximal nerve sites next to normal nerve segments in other nerves, i.e., tibial nerve (D, CSA $23 \mathrm{~mm}^{2}$ ). Areae enclosed by the discontinuous points in picture A and B depict CSA of the described nerve section, "A"means "area". Areae enclosed by circles in pictures C and D depict CSA of the described nerve section, "+" shows curser position, " 1 " the count of measured areae.

\section{Motor neuron Diseases}

Next to muscle ultrasound in motor neuron diseases such as ALS, nerve ultrasound can contribute important information concerning the nervous system [108,148,149]. Particularly atrophy of the distal ulnar nerve or the roots [104,108,150], for example, in lower motor neuron variants of ALS, might be a prognostic marker. Interestingly, this could not be shown in primary lateral sclerosis (PLS). Findings are thus indicating ultrasound as the key tool to identify PLS from the upper motor neuron dominant variant of ALS, which is clinically difficult to separate [151]. In ALS, nerve atrophy seems to progress during disease $[104,148,151,152]$. However, in the early course of disease, even focal nerve enlargement can rarely be seen [107]. Still, clinical presentation and course remains the most important fact. Nevertheless, if nerve enlargement is seen in patients with severe NCS pathology with or without conduction blocks $[102,103]$, a possible inflammation must be included in the therapeutic concept.

\section{Scoring Systems}

In general, demyelinating neuropathies regularly show nerve enlargement, whereas axonal ones do not $[34,129,130]$. However, many exceptions exist such as vasculitic PNP or amyloidosis. Therefore, a quantification of nerve enlargement including pattern analysis, anatomical predominance, echointensity and amount of nerve enlargement is necessary 
to avoid mis- or overinterpretation. Some authors suggest scoring tools to better decrypt several neuropathies by summing up characteristics of nerve alterations [149]. Craig Zaidman was the first to develop a classification of normal sized nerves, mild, regional or diffuse nerve enlargement for the differentiation of axonal neuropathies, GBS, CIDP and CMT1A [34]. CMT1A patients mostly showed a diffuse pattern, whereas CIDP patients exhibited a regional pattern.

Our colleagues from Bochum University Hospital developed the Bochum Ultrasound Score (BUS), which enables differentiation between GBS and CIDP in the early disease course $[150,153]$. More than two enlarged nerves in an analysis of the ulnar nerve (examined at Guyon loge and upper arm), the radial nerve (spiral groove) and the sural nerve points to the diagnosis of CIDP (Figure 5). This score is a reliable fast-track tool, which can be easily used in each neurophysiology unit.

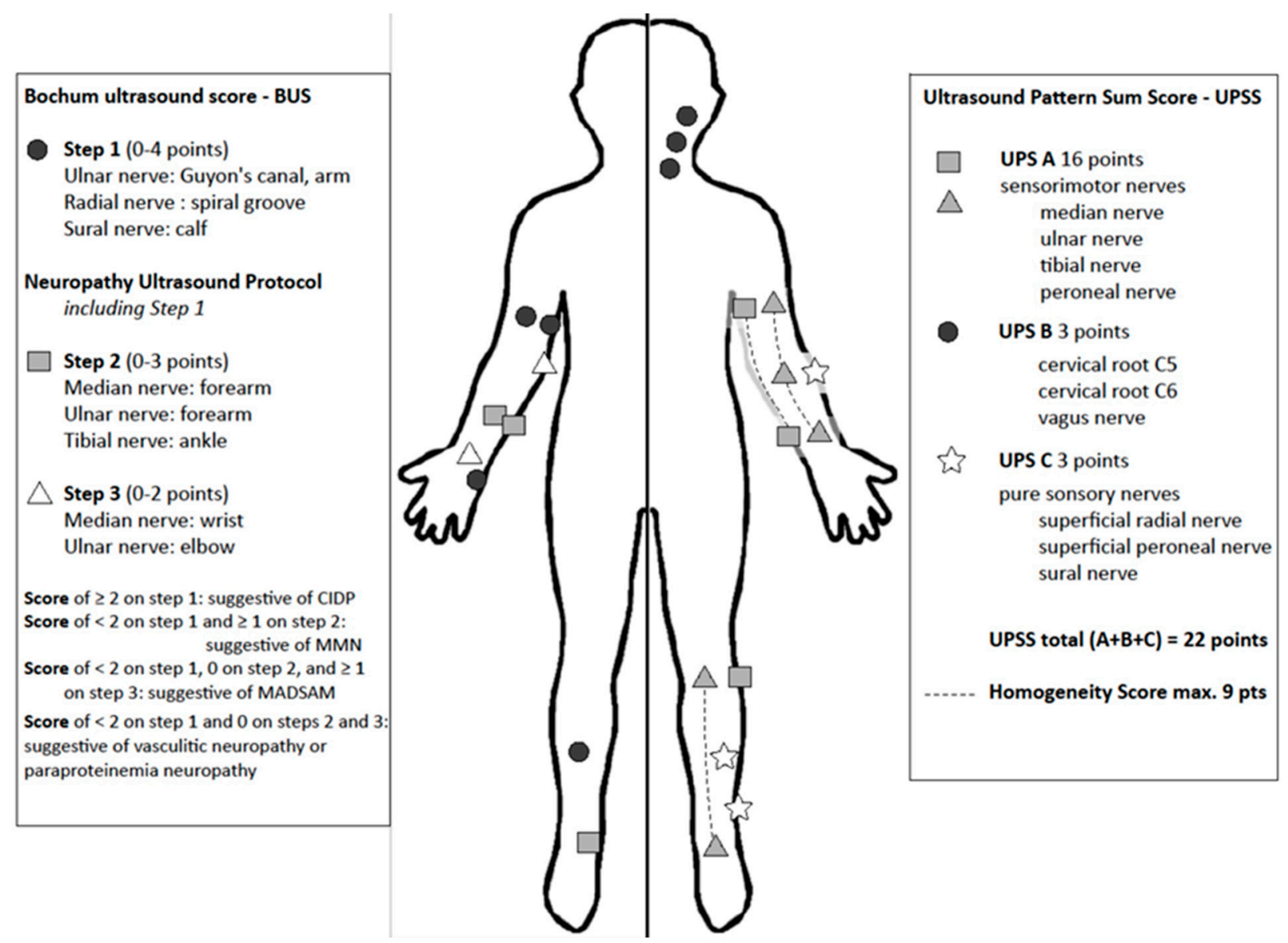

Figure 5. Measure points and scoring system of Bochum Ultrasound Score (BUS, left side), Neuropathy Ultrasound Protocol (NUP) and Ultrasound Pattern Sum Score (UPSS, right side). BUS and NUP are applied in three steps according to number of enlarged nerves. UPSS is performed in one step and the addition of homogeneity score allows differentiation of nerve in homogenous or heterogenous enlargement patterns.

A further established score is the ultrasound pattern sum score (UPSS) [19,87,138], which quantifies nerve enlargement at several nerve segments. It is subdivided in three parts: UPS $A$ for peripheral sensorimotor nerves, UPS $B$ for roots $C 5$ and 6 and vagus nerve and UPS $C$ for sensory nerves. Additionally, it includes further evaluation of homogeneity of nerve enlargement [87]. In this score, a maximum of 22 points can be reached, resembling significant nerve enlargement in all nerve segments with homogeneous distribution, as for example found in CMT1A. On the other hand, an enlarged UPSB score next to normal UPSA and UPSC scores hints to the diagnosis of GBS in a typical clinical context or any 
other pure radiculitis. An overall score lower than three points excludes inflammation or heredity of neuropathy with a negative predictive value of more than $90 \%$. A UPS A score larger than three points without root enlargement (UPS B) suggests the diagnosis of vasculitis. Additional evaluation of homogeneity of the nerves (median, ulnar and tibial nerve) enables differentiation of CMT1 and CIDP [87].

Next to the UPSS or BUS, Padua et al. described several echointensity classes in immune-mediated neuropathies [11], which proved its strength in a prospective study of Haertig et al. [12]. Further, regional or differential fascicle enlargement might be a hallmark in MMN or LSS [8,9]. Thus, a combination of nerve enlargement quantification, fascicle evaluation, echointensity classification and entrapment analysis might contribute to a better distinction of neuropathies. However, multicenter evaluation is still required concerning all mentioned scoring tools.

A summary of BUS and UPSS is shown in Figure 5. Noteworthy for these scores is their character as additive tools. These scoring tools must be interpreted in the context of nerve conduction, clinical findings and medical history. A UPSS Score of zero points does not exclude immune-mediated forms, for example GBS. However, the accuracy of the Zaidman classification, the UPSS and the BUS was rather excellent in a retrospective meta-analysis so far [149].

\section{Practical Approach Combining Electrophysiology and Nerve Ultrasound}

Although many aspects concerning the value of nerve ultrasound are still missing in the diagnosis of PNP, its use for several neuropathies has been widely proven. It might help to reduce the high number of unknown etiologies and thus support practitioners to target their diagnostic steps. Still, before performing ultrasound, profound knowledge of ultrasound technique, anatomy of the musculoskeletal and nervous system as well as its distinct pathologies is essential $[6,7]$. Thus, experts recommend international trainings and guidelines to learn and to perform ultrasound with common protocols [154,155]. Distinct ultrasound devices and probes might hamper this operationalization; however, this hurdle was already taken by other disciplines, too. Nevertheless, the authors propose the additive use of ultrasound, particularly in unclear cases of suggested inflammation. Further, its use as a biomarker for therapeutic response might be suitable in daily routine. Ultrasound is fast and cost-effective and thus could be widely used in contrast to other imaging tools [156]. Finally, we recommend an algorithm for how to handle ultrasound as an additive tool in the context of clinical examination and nerve conduction studies concerning the most important PNP variants and mimics (Figure 6). 


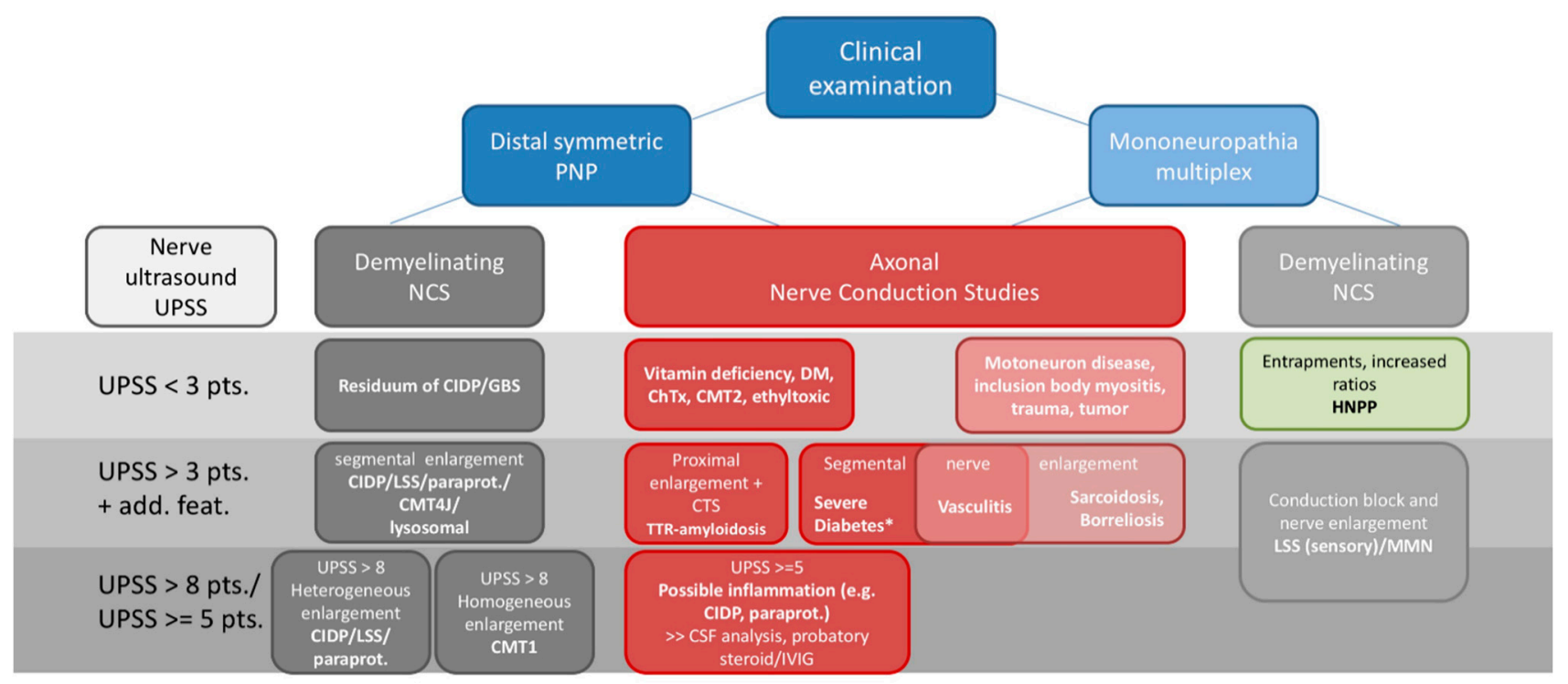

Figure 6. Proposed diagnostic algorithm and possible, most common differential diagnosis for clinical routine including clinical examination, nerve conduction studies and nerve ultrasound. * an additional inflammatory component might play a role in nerve enlargement. Abbreviations: $\mathrm{ChTx}=$ chemotherapy, $\mathrm{CIDP}=$ chronic inflammatory demyelinating polyneuropathy, $\mathrm{CMT}=$ Charcot Marie Tooth, CSF $=$ cerebrospinal fluid analysis, $\mathrm{CTS}=$ carpal tunnel syndrome, DM = diabetes mellitus, HNPP = hereditary neuropathy with pressure palsies, GBS = Guillain-Barre-Syndrome, IVIG = intravenous immunoglobulin, LSS = Lewis-Sumner Syndrome, MMN = multifocal motor neuropathy, NCS = nerve conduction studies, paraprot. $=$ paraproteinemic polyneuropathies, $\mathrm{PNP}=$ polyneuropathies, $\mathrm{TTR}=$ hereditary transthyretin related amyloidosis, UPSS = ultrasound pattern sum score.

\section{Limitations and Conclusions}

Examiners using ultrasound must bear in mind the limitations of nerve ultrasound. Most of the studies are single center based and thus sensitivities and specificities must be interpreted with care. Further, many distinct scoring tools have been used, which influenced the sensitivity and specificity significantly. To get profound values, multicentric studies including several neuropathy types are mandatory in the future. Normal data might depend on ethnicity, weight, height, and sex [17-20]. Particularly the examiner experience and the used ultrasound tool might influence image quality and thus interpretation. Profound knowledge of ultrasound is highly recommended and crucial for an accurate diagnosis. Clinical examination and NCS remain the actual gold standard for the evaluation of the peripheral nerve system and are indispensable. Of note, ultrasound has its limitations in deep layers, for example, lumbar plexus, lumbar roots and deep smaller nerves. Further, little is known about contrast enhanced nerve ultrasound. Herein, MRI is superior to ultrasound and thus the combination of both tools can be necessary in some neuropathies. Nonetheless, ultrasound might help to detect nerve alterations in otherwise non classifiable neuropathies (e.g., axonal predominant inflammatory neuropathy [12,72], or to differentiate between inherited and acquired neuropathies. Further, ultrasound might serve as a biomarker for therapy control; however, multicentric data are needed for this indication [12]. Table 1 summarizes all important key features concerning several polyneuropathies. 
Table 1. Overview of typical nerve conduction and ultrasound findings in various forms of polyneuropathies. A detailed description including references can be found in the text in the respective text sections.

\begin{tabular}{|c|c|c|c|c|}
\hline Diagnosis & $\begin{array}{l}\text { Predominant Nerve } \\
\text { Conduction Findings }\end{array}$ & $\begin{array}{l}\text { Common Ultrasound } \\
\text { Findings }\end{array}$ & Echointensity & Scores/Cut-Offs \\
\hline \multicolumn{5}{|c|}{ Hereditary Neuropathies } \\
\hline CMT1a & Demyelinating & $\begin{array}{c}\text { Homogeneous nerve } \\
\text { enlargement }\end{array}$ & Reduced & $\begin{array}{c}\text { UPSS }>8 \\
\mathrm{HS} \geq 4\end{array}$ \\
\hline CMT1b & Demyelinating & $\begin{array}{c}\text { Homogeneous nerve } \\
\text { enlargement (smaller } \\
\text { than CMT1a) }\end{array}$ & Reduced & $\begin{array}{c}\text { UPSS }>8 \\
\mathrm{HS}>3\end{array}$ \\
\hline Other CMT1/4 & Demyelinating & $\begin{array}{l}\text { Regional nerve } \\
\text { enlargement } \\
\text { (heterogeneous) }\end{array}$ & Insufficient data & Insufficient data \\
\hline CMT2 & Axonal & $\begin{array}{c}\text { No significant nerve } \\
\text { enlargement }\end{array}$ & Insufficient data & UPSS $<3$ \\
\hline HNPP & Nerve entrapment & $\begin{array}{l}\text { Enlargement at } \\
\text { entrapment sites }\end{array}$ & $\begin{array}{l}\text { Reduced at entrapment } \\
\text { sites }\end{array}$ & $\begin{array}{c}\text { UPSS }<3 \\
\text { Entrapment ratios }>1,5\end{array}$ \\
\hline ATTR & $\begin{array}{l}\text { Axonal and nerve } \\
\text { entrapment }\end{array}$ & $\begin{array}{l}\text { Proximal nerve } \\
\text { enlargement and at } \\
\text { entrapment sites }\end{array}$ & Reduced & $\begin{array}{c}\text { UPSS }>3, \\
\text { entrapment }\end{array}$ \\
\hline $\begin{array}{l}\text { SCA neuropathy/ } \\
\text { CANVAS }\end{array}$ & $\begin{array}{l}\text { Axonal (sensory } \\
\text { dominant) }\end{array}$ & $\begin{array}{l}\text { No nerve enlargement } \\
\text { (upper limb nerves } \\
<5 \mathrm{~mm}^{2} \text { in CANVAS } \\
\text { patients) }\end{array}$ & Increased & $\begin{array}{l}\text { Upper limb nerves } \\
<5 \mathrm{~mm}^{2}\end{array}$ \\
\hline
\end{tabular}

Metachromatic and

Adrenoleucodystrophies /

Cerebrotendinous

Xanthochromatosis

\section{Demyelinating,} homogeneous
Diffuse nerve enlargement
Reduced

UPSS > $3($ AMN $)$

\begin{tabular}{|c|c|c|c|c|}
\hline \multicolumn{5}{|c|}{ Acquired neuropathies } \\
\hline GBS & $\begin{array}{c}\text { Axonal } \\
\text { (AMAN/AMSAN), } \\
\text { demyelinating } \\
\text { (AIDP/MFS) }\end{array}$ & $\begin{array}{l}\text { Nerve root and vagus } \\
\text { nerve enlargement }\end{array}$ & Reduced & $\begin{array}{c}\text { UPSS }<5 \\
\text { UPSB } \geq 1 \text { UPSC }<1 \\
\text { BUS }<2\end{array}$ \\
\hline CIDP & $\begin{array}{c}\text { Demyelinating EFNS } \\
\text { criteria } \\
\text { (symmetric) }\end{array}$ & $\begin{array}{c}\text { Heterogeneous } \\
\text { enlargement of all } \\
\text { nerves (proximal } \\
\text { predominant, median } \\
\text { nerve, ulnar nerve, } \\
\text { nerve roots and plexus) }\end{array}$ & $\begin{array}{c}\text { Heterogeneous } \\
\text { (Class } 1 \text { reduced, Class } \\
2 \text { increased, Class } 3 \\
\text { mixed/ not enlarged) }\end{array}$ & $\begin{array}{l}\text { UPSS }>5 \\
\text { BUS }>1\end{array}$ \\
\hline MADSAM & $\begin{array}{l}\text { Demyelinating with } \\
\text { temporal dispersion } \\
\text { and conduction block } \\
\text { (asymmetric) }\end{array}$ & $\begin{array}{l}\text { Fascicular and } \\
\text { regionally restricted } \\
\text { nerve enlargement, also } \\
\text { resembling CIDP } \\
\text { pattern }\end{array}$ & Similar to CIDP & $\begin{array}{l}\text { UPSS }>3 \\
\text { UPSC }>0\end{array}$ \\
\hline $\begin{array}{l}\text { Multifocal Motor } \\
\text { Neuropathy }\end{array}$ & $\begin{array}{l}\text { Conduction block, only } \\
\text { motor nerves affected }\end{array}$ & $\begin{array}{c}\text { Fascicular and } \\
\text { regionally restricted } \\
\text { nerve enlargement, } \\
\text { correlating with } \\
\text { conduction block in up } \\
\text { to } 75 \%\end{array}$ & Reduced $>$ increased & $\begin{array}{c}\text { UPSS }>3 \\
\text { UPSC }<1 \text { (no sensory } \\
\text { nerves affected) }\end{array}$ \\
\hline Anti-MAG PNP & Demyelinating & Similar to CIDP & Similar to CIDP & Similar to CIDP \\
\hline
\end{tabular}


Table 1. Cont.

\begin{tabular}{|c|c|c|c|c|}
\hline Diagnosis & $\begin{array}{l}\text { Predominant Nerve } \\
\text { Conduction Findings }\end{array}$ & $\begin{array}{c}\text { Common Ultrasound } \\
\text { Findings }\end{array}$ & Echointensity & Scores/Cut-Offs \\
\hline MGUS-CIDP & Similar to CIDP & Similar to CIDP & Similar to CIDP & Similar to CIDP \\
\hline $\begin{array}{l}\text { Other PNP associated } \\
\text { with MGUS }\end{array}$ & Axonal & No enlargement & Insufficient data & UPSS $<3$ \\
\hline $\begin{array}{l}\text { Multiple Myeloma } \\
\text { associated PNP }\end{array}$ & Axonal & No enlargement & Insufficient data & UPSS $<3$ \\
\hline POEMS & $\begin{array}{l}\text { Demyelinating } \\
\text { (homogeneous) }\end{array}$ & $\begin{array}{c}\text { Heterogeneous nerve } \\
\text { enlargement, } \\
\text { entrapment sites }\end{array}$ & Insufficient data & UPSS $>3$ \\
\hline Vasculitis & Axonal (asymmetric) & $\begin{array}{c}\text { Focal nerve } \\
\text { enlargement in } \\
\text { symptomatic nerves }\end{array}$ & Increased & $\begin{array}{c}\text { UPSS 3-9 } \\
\text { Multifocal nerve } \\
\text { enlargement of } \geq 1 \\
\text { nerve }\end{array}$ \\
\hline Diabetic PNP & $\begin{array}{c}\text { Axonal > } \\
\text { >demyelinating }\end{array}$ & $\begin{array}{l}\text { Slight nerve } \\
\text { enlargement (e.g., } \\
\text { entrapment sites) }\end{array}$ & Inconsistent data & UPSS $<3$ \\
\hline $\begin{array}{l}\text { ChTx induced } \\
\text { neuropathies }\end{array}$ & Axonal & $\begin{array}{c}\text { No significant nerve } \\
\text { enlargement }\end{array}$ & Increased & UPSS $<3$ \\
\hline $\begin{array}{c}\text { Other axonal } \\
\text { neuropathies (e.g., } \\
\text { vitamin deficiency) }\end{array}$ & Axonal & No nerve enlargement & Insufficient data & UPSS $<3$ \\
\hline
\end{tabular}

Abbreviations: AMAN: Acute motor axonal neuropathy, AMSAN: Acute motor-sensory axonal neuropathy, AIDP: Acute inflammatory demyelinating polyneuropathy, AMN: Adrenoleucodystrophies, ATTR: Hereditary transthyretin related amyloidosis, BUS: Bochum Ultrasound Score, CANVAS: Cerebellar ataxia neuropathy vestibular areflexia syndrome, ChTx: Chemotherapy, CIDP: Chronic inflammatory demyelinating polyneuropathies, CMT: Charcot Marie Tooth Neuropathy, GBS: Guillain-Barre syndrome, HNPP: Hereditary neuropathy with liability to pressure palsies, HS: Homogeneity score, MADSAM: Multifocal acquired demyelinating sensory and motor neuropathy, MAG: Myelin associated glycoprotein, MFS: Miller-Fisher syndrome, MGUS: Monoclonal gammopathy of undetermined significance, PNP: Polyneuropathy, POEMS: Polyneuropathy, organomegaly, endocrinopathy, monoclonal protein, skin changes, SCA: Spino-cerebellar ataxia, UPSA-C: Ultrasound pattern score A-C, UPSS: Ultrasound pattern sum score.

Therefore, ultrasound should be included as a basic tool in every neurophysiology department as it adds important information.

Author Contributions: Conceptualization, M.K., A.G., N.W. and S.W., writing-original draft preparation, M.K., A.G., N.W. and S.W., writing-review and editing, M.D., K.G.-H., J.-H.S., J.W., J.K., C.K.; visualization N.W. and S.W. All authors have read and agreed to the published version of the manuscript.

Funding: M.K. received a reimbursement for congress participation by Biogen GmbH. A.G. received speakers honorary from CSL Behring, Grifols, Pfizer, Alnylam. N.W. received travel support to attend scientific meetings by Canon Medical Systems and CSL Behring Pharmaceuticals. N.W. further received research funding from the German Ultrasound Society (DEGUM, Project TUNAP) and is currently receiving a scholarship from the Medical Faculty Tuebingen (Clinician Scientist).

Conflicts of Interest: The authors declare no conflict of interest regarding this paper. The funders had no role in the design of the study; in the collection, analyses, or interpretation of data; in the writing of the manuscript, or in the decision to publish the results. 


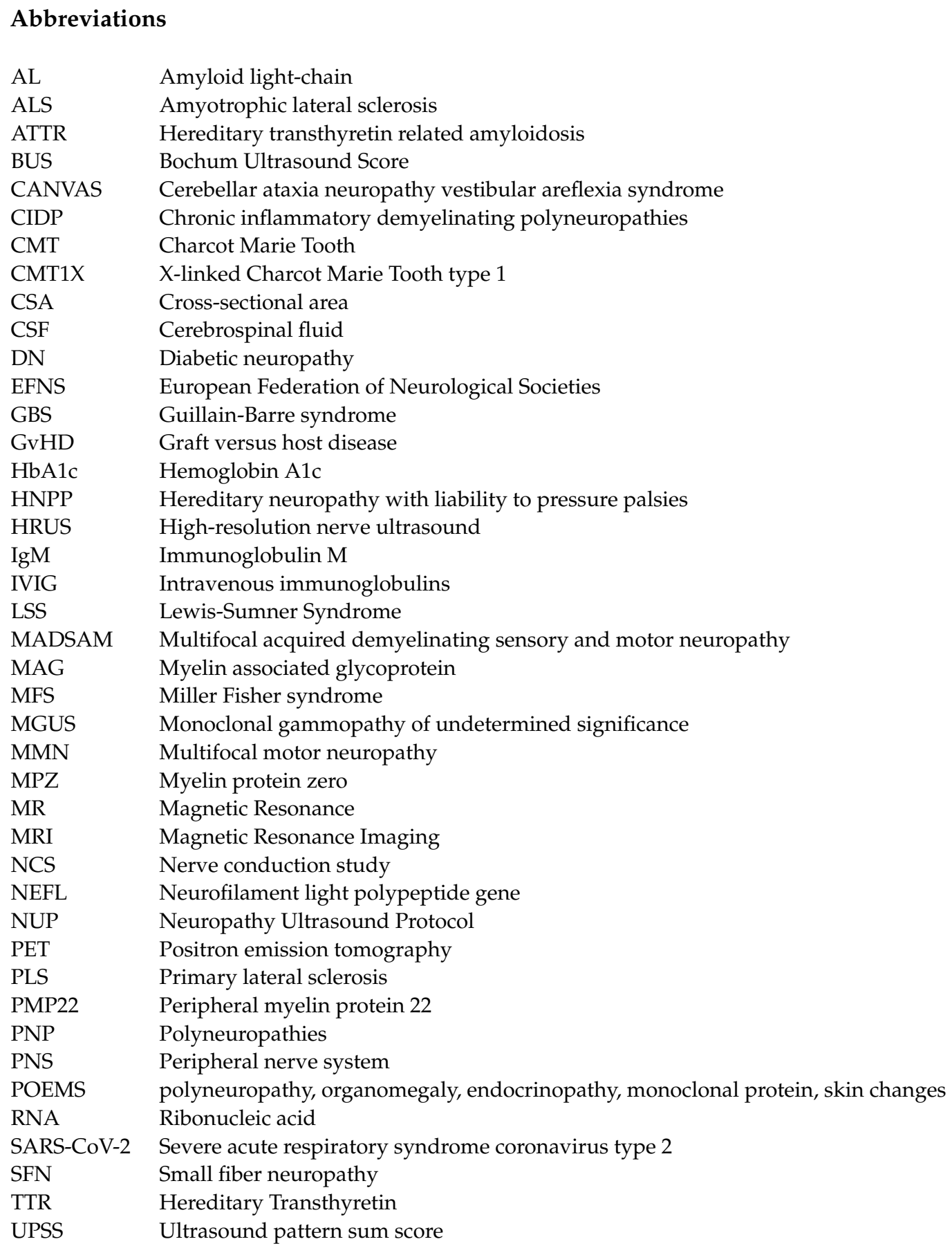

\section{References}

1. Joint Task Force of the EFNS and the PNS European Federation of Neurological Societies/Peripheral Nerve Society guideline on management of multifocal motor neuropathy. Report of a joint task force of the European Federation of Neurological Societies and the Peripheral Nerve Society-First revision. J. Peripher. Nerv. Syst. 2010, 15, 295-301. [CrossRef] [PubMed]

2. Kollmer, J.; Hund, E.; Hornung, B.; Hegenbart, U.; Schonland, S.O.; Kimmich, C.; Kristen, A.V.; Purrucker, J.; Rocken, C.; Heiland, S.; et al. In vivo detection of nerve injury in familial amyloid polyneuropathy by magnetic resonance neurography. Brain 2015, 138, 549-562. [CrossRef] [PubMed]

3. Decard, B.F.; Pham, M.; Grimm, A. Ultrasound and MRI of nerves for monitoring disease activity and treatment effects in chronic dysimmune neuropathies-Current concepts and future directions. Clin. Neurophysiol. 2018, 129, 155-167. [CrossRef] [PubMed]

4. Baute Penry, V.; Cartwright, M.S. Neuromuscular Ultrasound for Peripheral Neuropathies. Semin. Neurol. 2019, 39, 542-548. [CrossRef]

5. Telleman, J.A.; Grimm, A.; Goedee, S.; Visser, L.H.; Zaidman, C.M. Nerve ultrasound in polyneuropathies. Muscle Nerve 2018, 57, 716-728. [CrossRef] 
6. Walker, F.O.; Cartwright, M.S.; Alter, K.E.; Visser, L.H.; Hobson-Webb, L.D.; Padua, L.; Strakowski, J.A.; Preston, D.C.; Boon, A.J.; Axer, H.; et al. Indications for neuromuscular ultrasound: Expert opinion and review of the literature. Clin. Neurophysiol. 2018, 129, 2658-2679. [CrossRef]

7. Dengler, R.; De Carvalho, M.; Shahrizaila, N.; Nodera, H.; Vucic, S.; Grimm, A.; Padua, L.; Schreiber, S.; Kneiser, M.K.; HobsonWebb, L.D.; et al. AANEM-IFCN Glossary of Terms in Neuromuscular Electrodiagnostic Medicine and Ultrasound. Muscle Nerve 2020, 62, 10-12. [CrossRef]

8. Grimm, A.; Winter, N.; Rattay, T.W.; Hartig, F.; Dammeier, N.M.; Auffenberg, E.; Koch, M.; Axer, H. A look inside the nerveMorphology of nerve fascicles in healthy controls and patients with polyneuropathy. Clin. Neurophysiol. 2017, 128, 2521-2526. [CrossRef]

9. Rattay, T.W.; Winter, N.; Décard, B.F.; Dammeier, N.M.; Härtig, F.; Ceanga, M.; Axer, H.; Grimm, A. Nerve ultrasound as follow-up tool in treated multifocal motor neuropathy. Eur. J. Neurol. 2017, 24, 1125-1134. [CrossRef]

10. Cartwright, M.S.; Baute, V.; Caress, J.B.; Walker, F.O. Ultrahigh-frequency ultrasound of fascicles in the median nerve at the wrist. Muscle Nerve 2017, 56, 819-822. [CrossRef]

11. Padua, L.; Granata, G.; Sabatelli, M.; Inghilleri, M.; Lucchetta, M.; Luigetti, M.; Coraci, D.; Martinoli, C.; Briani, C. Heterogeneity of root and nerve ultrasound pattern in CIDP patients. Clin. Neurophysiol. 2014, 125, 160-165. [CrossRef] [PubMed]

12. Hartig, F.; Ross, M.; Dammeier, N.M.; Fedtke, N.; Heiling, B.; Axer, H.; Decard, B.F.; Auffenberg, E.; Koch, M.; Rattay, T.W.; et al. Nerve Ultrasound Predicts Treatment Response in Chronic Inflammatory Demyelinating Polyradiculoneuropathy-a Prospective Follow-Up. Neurotherapeutics 2018, 15, 439-451. [CrossRef] [PubMed]

13. Fisse, A.L.; Pitarokoili, K.; Motte, J.; Gamber, D.; Kerasnoudis, A.; Gold, R.; Yoon, M.S. Nerve echogenicity and intranerve CSA variability in high-resolution nerve ultrasound (HRUS) in chronic inflammatory demyelinating polyneuropathy (CIDP). J. Neurol. 2019, 266, 468-475. [CrossRef] [PubMed]

14. Gamber, D.; Motte, J.; Kerasnoudis, A.; Yoon, M.S.; Gold, R.; Pitarokoili, K.; Fisse, A.L. High-Resolution Nerve Ultrasound to Assess Nerve Echogenicity, Fascicular Count, and Cross-Sectional Area Using Semiautomated Analysis. J. Neuroimaging 2020, 30, 493-502. [CrossRef]

15. Goedee, H.S.; Brekelmans, G.J.; Visser, L.H. Multifocal enlargement and increased vascularization of peripheral nerves detected by sonography in CIDP: A pilot study. Clin. Neurophysiol. 2014, 125, 154-159. [CrossRef]

16. He, Y.; Xiang, X.; Zhu, B.H.; Qiu, L. Shear wave elastography evaluation of the median and tibial nerve in diabetic peripheral neuropathy. Quant. Imaging Med. Surg. 2019, 9, 273-282. [CrossRef]

17. Boehm, J.; Scheidl, E.; Bereczki, D.; Schelle, T.; Aranyi, Z. High-resolution ultrasonography of peripheral nerves: Measurements on 14 nerve segments in 56 healthy subjects and reliability assessments. Ultraschall Med. 2014, 35, 459-467. [CrossRef]

18. Cartwright, M.S.; Passmore, L.V.; Yoon, J.S.; Brown, M.E.; Caress, J.B.; Walker, F.O. Cross-sectional area reference values for nerve ultrasonography. Muscle Nerve 2008, 37, 566-571. [CrossRef]

19. Grimm, A.; Axer, H.; Heiling, B.; Winter, N. Nerve ultrasound normal values-Readjustment of the ultrasound pattern sum score UPSS. Clin. Neurophysiol. 2018, 129, 1403-1409. [CrossRef]

20. Tagliafico, A.; Martinoli, C. Reliability of side-to-side sonographic cross-sectional area measurements of upper extremity nerves in healthy volunteers. J. Ultrasound Med. 2013, 32, 457-462. [CrossRef]

21. Padua, L.; Martinoli, C.; Pazzaglia, C.; Lucchetta, M.; Granata, G.; Erra, C.; Briani, C. Intra- and internerve cross-sectional area variability: New ultrasound measures. Muscle Nerve 2012, 45, 730-733. [CrossRef] [PubMed]

22. Qrimli, M.; Ebadi, H.; Breiner, A.; Siddiqui, H.; Alabdali, M.; Abraham, A.; Lovblom, L.E.; Perkins, B.A.; Bril, V. Reference values for ultrasonograpy of peripheral nerves. Muscle Nerve 2016, 53, 538-544. [CrossRef] [PubMed]

23. Kerasnoudis, A.; Pitarokoili, K.; Behrendt, V.; Gold, R.; Yoon, M.S. Cross sectional area reference values for sonography of peripheral nerves and brachial plexus. Clin. Neurophysiol. 2013, 124, 1881-1888. [CrossRef] [PubMed]

24. Schubert, C.; Grimm, A.S.; Stahl, J.H.; Kupper, H.; Kegele, J.; Wittlinger, J.; Serna-Higuita, L.; Winter, N.; Groeschel, S.; Grimm, A. Nerve ultrasound reference data in children from two to seven years. Clin. Neurophysiol. 2020, 131, 859-865. [CrossRef]

25. Druzhinin, D.; Naumova capital Ie, C.; Nikitin, S. Nerve ultrasound normal values in children and young adults. Muscle Nerve 2019, 60, 757-761. [CrossRef]

26. Bathala, L.; Kumar, P.; Kumar, K.; Visser, L.H. Ultrasonographic cross-sectional area normal values of the ulnar nerve along its course in the arm with electrophysiological correlations in 100 Asian subjects. Muscle Nerve 2013, 47, 673-676. [CrossRef]

27. Grimm, A.S.; Schubert, C.; Grimm, A.; Stahl, J.H.; Küpper, H.; Horber, V.; Kegele, J.; Willikens, S.; Wittlinger, J.; Serna-Higuita, L.; et al. Normative Observational Nerve Ultrasound Values in School-Age Children and Adolescents and Their Application to Hereditary Neuropathies. Front. Neurol. 2020, 11, 303. [CrossRef]

28. Martinoli, C.; Schenone, A.; Bianchi, S.; Mandich, P.; Caponetto, C.; Abbruzzese, M.; Derchi, L.E. Sonography of the median nerve in Charcot-Marie-Tooth disease. AJR Am. J. Roentgenol. 2002, 178, 1553-1556. [CrossRef]

29. Pazzaglia, C.; Minciotti, I.; Coraci, D.; Briani, C.; Padua, L. Ultrasound assessment of sural nerve in Charcot-Marie-Tooth 1A neuropathy. Clin. Neurophysiol. 2013, 124, 1695-1699. [CrossRef]

30. Schreiber, S.; Oldag, A.; Kornblum, C.; Kollewe, K.; Kropf, S.; Schoenfeld, A.; Feistner, H.; Jakubiczka, S.; Kunz, W.S.; Scherlach, C.; et al. Sonography of the median nerve in CMT1A, CMT2A, CMTX, and HNPP. Muscle Nerve 2013, 47, 385-395. [CrossRef] 
31. Goedee, S.H.; Brekelmans, G.J.; van den Berg, L.H.; Visser, L.H. Distinctive patterns of sonographic nerve enlargement in CharcotMarie-Tooth type 1A and hereditary neuropathy with pressure palsies. Clin. Neurophysiol. 2015, 126, 1413-1420. [CrossRef] [PubMed]

32. Noto, Y.; Shiga, K.; Tsuji, Y.; Mizuta, I.; Higuchi, Y.; Hashiguchi, A.; Takashima, H.; Nakagawa, M.; Mizuno, T. Nerve ultrasound depicts peripheral nerve enlargement in patients with genetically distinct Charcot-Marie-Tooth disease. J. Neurol. Neurosurg Psychiatry 2015, 86, 378-384. [CrossRef] [PubMed]

33. Yiu, E.M.; Brockley, C.R.; Lee, K.J.; Carroll, K.; de Valle, K.; Kennedy, R.; Rao, P.; Delatycki, M.B.; Ryan, M.M. Peripheral nerve ultrasound in pediatric Charcot-Marie-Tooth disease type 1A. Neurology 2015, 84, 569-574. [CrossRef] [PubMed]

34. Zaidman, C.M.; Harms, M.B.; Pestronk, A. Ultrasound of inherited vs. acquired demyelinating polyneuropathies. J. Neurol. 2013, 260, 3115-3121. [CrossRef]

35. Sugimoto, T.; Ochi, K.; Hosomi, N.; Takahashi, T.; Ueno, H.; Nakamura, T.; Nagano, Y.; Maruyama, H.; Kohriyama, T.; Matsumoto, M. Ultrasonographic nerve enlargement of the median and ulnar nerves and the cervical nerve roots in patients with demyelinating Charcot-Marie-Tooth disease: Distinction from patients with chronic inflammatory demyelinating polyneuropathy. J. Neurol. 2013, 260, 2580-2587. [CrossRef]

36. Grimm, A.; Rasenack, M.; Athanasopoulou, I.M.; Dammeier, N.M.; Lipski, C.; Wolking, S.; Vittore, D.; Décard, B.F.; Axer, H. The modified ultrasound pattern sum score mUPSS as additional diagnostic tool for genetically distinct hereditary neuropathies. $J$. Neurol. 2016, 263, 221-230. [CrossRef]

37. Zanette, G.; Fabrizi, G.M.; Taioli, F.; Lauriola, M.F.; Badari, A.; Ferrarini, M.; Cavallaro, T.; Tamburin, S. Nerve ultrasound findings differentiate Charcot-Marie-Tooth disease (CMT) 1A from other demyelinating CMTs. Clin. Neurophysiol. 2018, 129, $2259-2267$. [CrossRef]

38. Zanette, G.; Tamburin, S.; Taioli, F.; Lauriola, M.F.; Badari, A.; Ferrarini, M.; Cavallaro, T.; Fabrizi, G.M. Nerve size correlates with clinical severity in Charcot-Marie-Tooth disease 1A. Muscle Nerve 2019, 60, 744-748. [CrossRef]

39. Cartwright, M.S.; Brown, M.E.; Eulitt, P.; Walker, F.O.; Lawson, V.H.; Caress, J.B. Diagnostic nerve ultrasound in Charcot-MarieTooth disease type 1B. Muscle Nerve 2009, 40, 98-102. [CrossRef]

40. Luigetti, M.; Sabatelli, M.; Bellone, E.; Fabrizi, G.M.; Padua, L.; Granata, G. Nerve ultrasound in patients with CMT1C: Description of 3 cases. Muscle Nerve 2015, 51, 781-782. [CrossRef]

41. Castoro, R.; Crisp, J.; Caress, J.B.; Li, J.; Cartwright, M.S. Segmental nerve enlargement in CMT4J. Muscle Nerve 2020, 61, E44-E46. [CrossRef] [PubMed]

42. Pimentel, N.; Tiongson, E.; Mitchell, W.; Ramos-Platt, L. Case Series: Pediatric Patients with Concomitant Genetic Neuropathy Syndromes and Immune Mediated Polyneuropathy. (1073). Neurology 2020, 94, 1073.

43. Dyck, P.J.; Swanson, C.J.; Low, P.A.; Bartleson, J.D.; Lambert, E.H. Prednisone-responsive hereditary motor and sensory neuropathy. Mayo Clin. Proc. 1982, 57, 239-246. [PubMed]

44. Martini, R.; Toyka, K.V. Immune-mediated components of hereditary demyelinating neuropathies: Lessons from animal models and patients. Lancet Neurol. 2004, 3, 457-465. [CrossRef]

45. Grimm, A.; Winter, N.; Wolking, S.; Vittore, D.; Biskup, S.; Axer, H. Nerve enlargement in an unusual case of inflammatory neuropathy and new gene mutation-morphology is the key. Neurol. Sci. 2017, 38, 1525-1527. [CrossRef] [PubMed]

46. Hooper, D.R.; Lawson, W.; Smith, L.; Baker, S.K. Sonographic features in hereditary neuropathy with liability to pressure palsies. Muscle Nerve 2011, 44, 862-867. [CrossRef]

47. Beekman, R.; Visser, L.H. Sonographic detection of diffuse peripheral nerve enlargement in hereditary neuropathy with liability to pressure palsies. J. Clin. Ultrasound 2002, 30, 433-436. [CrossRef]

48. Kim, S.H.; Yang, S.N.; Yoon, J.S.; Park, B.J. Sonographic evaluation of the peripheral nerves in hereditary neuropathy with liability to pressure palsies: A case report. Ann. Rehabil. Med. 2014, 38, 109-115. [CrossRef]

49. Bayrak, A.O.; Bayrak, I.K.; Battaloglu, E.; Ozes, B.; Yildiz, O.; Onar, M.K. Ultrasonographic findings in hereditary neuropathy with liability to pressure palsies. Neurol. Res. 2015, 37, 106-111. [CrossRef]

50. Ginanneschi, F.; Filippou, G.; Giannini, F.; Carluccio, M.A.; Adinolfi, A.; Frediani, B.; Dotti, M.T.; Rossi, A. Sonographic and electrodiagnostic features of hereditary neuropathy with liability to pressure palsies. J. Peripher. Nerv. Syst. 2012, 17, 391-398. [CrossRef]

51. Dohrn, M.F.; Auer-Grumbach, M.; Baron, R.; Birklein, F.; Escolano-Lozano, F.; Geber, C.; Grether, N.; Hagenacker, T.; Hund, E.; Sachau, J.; et al. Chance or challenge, spoilt for choice? New recommendations on diagnostic and therapeutic considerations in hereditary transthyretin amyloidosis with polyneuropathy: The German/Austrian position and review of the literature. J. Neurol. 2020. [CrossRef] [PubMed]

52. Gertz, M.A.; Mauermann, M.L.; Grogan, M.; Coelho, T. Advances in the treatment of hereditary transthyretin amyloidosis: A review. Brain. Behav. 2019, 9, e01371. [CrossRef] [PubMed]

53. Moshe-Lilie, O.; Dimitrova, D.; Heitner, S.B.; Brannagan, T.H., 3rd; Zivkovic, S.; Hanna, M.; Masri, A.; Polydefkis, M.; Berk, J.L.; Gertz, M.A.; et al. TTR gene silencing therapy in post liver transplant hereditary ATTR amyloidosis patients. Amyloid 2020, 27, 250-253. [CrossRef] [PubMed]

54. Granata, G.; Luigetti, M.; Coraci, D.; Del Grande, A.; Romano, A.; Bisogni, G.; Bramanti, P.; Rossini, P.M.; Sabatelli, M.; Padua, L. Ultrasound evaluation in transthyretin-related amyloid neuropathy. Muscle Nerve 2014, 50, 372-376. [CrossRef] [PubMed] 
55. Podnar, S.; Sarafov, S.; Tournev, I.; Omejec, G.; Zidar, J. Peripheral nerve ultrasonography in patients with transthyretin amyloidosis. Clin. Neurophysiol. 2017, 128, 505-511. [CrossRef] [PubMed]

56. Salvalaggio, A.; Coraci, D.; Cacciavillani, M.; Obici, L.; Mazzeo, A.; Luigetti, M.; Pastorelli, F.; Grandis, M.; Cavallaro, T.; Bisogni, G.; et al. Nerve ultrasound in hereditary transthyretin amyloidosis: Red flags and possible progression biomarkers. J. Neurol. 2020. [CrossRef]

57. Rasenack, M.; Proebstel, A.K.; Athanasopoulou, I.M.; Decard, B.F.; Grimm, A. Nerve Hypertrophy in Primary Amyloidosis. Muscle Nerve 2016, 54, 510-512. [CrossRef] [PubMed]

58. Zaidman, C.M.; Al-Lozi, M.; Pestronk, A. Peripheral nerve size in normals and patients with polyneuropathy: An ultrasound study. Muscle Nerve 2009, 40, 960-966. [CrossRef]

59. Di Pasquale, A.; Morino, S.; Loreti, S.; Bucci, E.; Vanacore, N.; Antonini, G. Peripheral nerve ultrasound changes in CIDP and correlations with nerve conduction velocity. Neurology 2015, 84, 803-809. [CrossRef]

60. Tazawa, K.; Matsuda, M.; Yoshida, T.; Shimojima, Y.; Gono, T.; Morita, H.; Kaneko, T.; Ueda, H.; Ikeda, S. Spinal nerve root hypertrophy on MRI: Clinical significance in the diagnosis of chronic inflammatory demyelinating polyradiculoneuropathy. Intern. Med. 2008, 47, 2019-2024. [CrossRef]

61. Adachi, Y.; Sato, N.; Okamoto, T.; Sasaki, M.; Komaki, H.; Yamashita, F.; Kida, J.; Takahashi, T.; Matsuda, H. Brachial and lumbar plexuses in chronic inflammatory demyelinating polyradiculoneuropathy: MRI assessment including apparent diffusion coefficient. Neuroradiology 2011, 53, 3-11. [CrossRef] [PubMed]

62. Sinclair, C.D.; Miranda, M.A.; Cowley, P.; Morrow, J.M.; Davagnanam, I.; Mehta, H.; Hanna, M.G.; Koltzenburg, M.; Reilly, M.M.; Yousry, T.A.; et al. MRI shows increased sciatic nerve cross sectional area in inherited and inflammatory neuropathies. J. Neurol. Neurosurg. Psychiatry 2011, 82, 1283-1286. [CrossRef] [PubMed]

63. Lozeron, P.; Lacour, M.C.; Vandendries, C.; Theaudin, M.; Cauquil, C.; Denier, C.; Lacroix, C.; Adams, D. Contribution of plexus MRI in the diagnosis of atypical chronic inflammatory demyelinating polyneuropathies. J. Neurol. Sci. 2016, 360, 170-175. [CrossRef] [PubMed]

64. Grimm, A.; Vittore, D.; Schubert, V.; Rasenack, M.; Décard, B.F.; Heiling, B.; Hammer, N.; Axer, H. Ultrasound aspects in therapy-naive CIDP compared to long-term treated CIDP. J. Neurol. 2016, 263, 1074-1082. [CrossRef] [PubMed]

65. Kerasnoudis, A.; Pitarokoili, K.; Behrendt, V.; Gold, R.; Yoon, M.S. Correlation of nerve ultrasound, electrophysiological and clinical findings in chronic inflammatory demyelinating polyneuropathy. J. Neuroimaging 2015, 25, 207-216. [CrossRef] [PubMed]

66. Imamura, K.; Tajiri, Y.; Kowa, H.; Nakashima, K. Peripheral nerve hypertrophy in chronic inflammatory demyelinating polyradiculoneuropathy detected by ultrasonography. Intern. Med. 2009, 48, 581-582. [CrossRef]

67. Goedee, H.S.; van der Pol, W.L.; van Asseldonk, J.H.; Franssen, H.; Notermans, N.C.; Vrancken, A.J.; van Es, M.A.; Nikolakopoulos, S.; Visser, L.H.; van den Berg, L.H. Diagnostic value of sonography in treatment-naive chronic inflammatory neuropathies. Neurology 2017, 88, 143-151. [CrossRef]

68. Herraets, I.J.T.; Goedee, H.S.; Telleman, J.A.; van Eijk, R.P.A.; Verhamme, C.; Saris, C.G.J.; Eftimov, F.; van Alfen, N.; van Asseldonk, J.T.; Visser, L.H.; et al. Nerve ultrasound for diagnosing chronic inflammatory neuropathy: A multicenter validation study. Neurology 2020, 95, e1745-e1753. [CrossRef]

69. Schreiber, S.; Schreiber, F.; Peter, A.; Isler, E.; Dorner, M.; Heinze, H.J.; Petri, S.; Tempelmann, C.; Nestor, P.J.; Grimm, A.; et al. 7T MR neurography-ultrasound fusion for peripheral nerve imaging. Muscle Nerve 2020, 61, 521-526. [CrossRef]

70. Oudeman, J.; Eftimov, F.; Strijkers, G.J.; Schneiders, J.J.; Roosendaal, S.D.; Engbersen, M.P.; Froeling, M.; Goedee, H.S.; van Doorn, P.A.; Caan, M.W.A.; et al. Diagnostic accuracy of MRI and ultrasound in chronic immune-mediated neuropathies. Neurology 2020, 94, e62-e74. [CrossRef]

71. Goedee, H.S.; Herraets, I.J.T.; Visser, L.H.; Franssen, H.; van Asseldonk, J.H.; van der Pol, W.L.; van den Berg, L.H. Nerve ultrasound can identify treatment-responsive chronic neuropathies without electrodiagnostic features of demyelination. Muscle Nerve 2019, 60, 415-419. [CrossRef] [PubMed]

72. Herraets, I.J.T.; Goedee, H.S.; Telleman, J.A.; van Eijk, R.P.A.; van Asseldonk, J.T.; Visser, L.H.; van den Berg, L.H.; van der Pol, W.L. Nerve ultrasound improves detection of treatment-responsive chronic inflammatory neuropathies. Neurology 2020, 94, e1470-e1479. [CrossRef] [PubMed]

73. Winter, N.; Dammeier, N.; Schäffer, E.; Bornemann, A.; Stahl, J.H.; Herlan, S.; Schuhmann, M.U.; Grimm, A. Nerve Ultrasonography as an Additive Tool to Clinical Examination and Electrodiagnostics in Sporadic Mononeuritis-Imaging is the Key. Ultraschall Med. 2019, 40, 465-472. [CrossRef] [PubMed]

74. Zaidman, C.M.; Pestronk, A. Nerve size in chronic inflammatory demyelinating neuropathy varies with disease activity and therapy response over time: A retrospective ultrasound study. Muscle Nerve 2014, 50, 733-738. [CrossRef]

75. Kerasnoudis, A.; Pitarokoili, K.; Gold, R.; Yoon, M.S. Nerve Ultrasound and Electrophysiology for Therapy Monitoring in Chronic Inflammatory Demyelinating Polyneuropathy. J. Neuroimaging 2015, 25, 931-939. [CrossRef]

76. Hokkoku, K.; Matsukura, K.; Uchida, Y.; Kuwabara, M.; Furukawa, Y.; Tsukamoto, H.; Hatanaka, Y.; Sonoo, M. Quantitative muscle ultrasound is useful for evaluating secondary axonal degeneration in chronic inflammatory demyelinating polyneuropathy. Brain Behav. 2017, 7, e00812. [CrossRef]

77. Puma, A.; Azulay, N.; Grecu, N.; Suply, C.; Panicucci, E.; Cambieri, C.; Villa, L.; Raffaelli, C.; Sacconi, S. Comparison of high-frequency and ultrahigh-frequency probes in chronic inflammatory demyelinating polyneuropathy. J. Neurol. 2019, 266, 2277-2285. [CrossRef] 
78. Athanasopoulos, D.; Motte, J.; Fisse, A.L.; Grueter, T.; Trampe, N.; Sturm, D.; Tegenthoff, M.; Sgodzai, M.; Klimas, R.; Querol, L.; et al. Longitudinal study on nerve ultrasound and corneal confocal microscopy in NF155 paranodopathy. Ann. Clin. Transl. Neurol. 2020, 7, 1061-1068. [CrossRef]

79. Franques, J.; Chapon, F.; Devaux, J.; Mathis, S. Teaching NeuroImages: Cranial nerve hypertrophy in IgG4 anti-neurofascin 155 antibody-positive polyneuropathy. Neurology 2017, 88, e52. [CrossRef]

80. Simon, N.G.; Kiernan, M.C. Precise correlation between structural and electrophysiological disturbances in MADSAM neuropathy. Neuromuscul. Disord. NMD 2015, 25, 904-907. [CrossRef]

81. Kerasnoudis, A. Ultrasonography of MADSAM neuropathy: Focal nerve enlargements at sites of existing and resolved conduction blocks. Neuromuscul. Disord. NMD 2012, 22, 1032. [CrossRef] [PubMed]

82. Scheidl, E.; Böhm, J.; Simó, M.; Rózsa, C.; Bereznai, B.; Kovács, T.; Arányi, Z. Ultrasonography of MADSAM neuropathy: Focal nerve enlargements at sites of existing and resolved conduction blocks. Neuromuscul. Disord. NMD 2012, 22, 627-631. [CrossRef] [PubMed]

83. Neubauer, C.; Gruber, H.; Bauerle, J.; Egger, K. Ultrasonography of Multifocal Acquired Demyelinating Sensory and Motor Neuropathy (MADSAM). Clin. Neuroradiol. 2015, 25, 423-425. [CrossRef] [PubMed]

84. Grimm, A.; Thomaser, A.L.; Peters, N.; Fuhr, P. Neurological picture. Vagal hypertrophy in immune-mediated neuropathy visualised with high-resolution ultrasound (HR-US). J. Neurol. Neurosurg. Psychiatry 2015, 86, 1277-1278. [CrossRef]

85. Granata, G.; Pazzaglia, C.; Calandro, P.; Luigetti, M.; Martinoli, C.; Sabatelli, M.; Padua, L. Ultrasound visualization of nerve morphological alteration at the site of conduction block. Muscle Nerve 2009, 40, 1068-1070. [CrossRef]

86. Dorner, M.; Schreiber, F.; Stephanik, H.; Tempelmann, C.; Winter, N.; Stahl, J.H.; Wittlinger, J.; Willikens, S.; Kramer, M.; Heinze, H.J.; et al. Peripheral Nerve Imaging Aids in the Diagnosis of Immune-Mediated Neuropathies-A Case Series. Diagnostics 2020, 10, 535. [CrossRef]

87. Grimm, A.; Vittore, D.; Schubert, V.; Lipski, C.; Heiling, B.; Decard, B.F.; Axer, H. Ultrasound pattern sum score, homogeneity score and regional nerve enlargement index for differentiation of demyelinating inflammatory and hereditary neuropathies. Clin. Neurophysiol. 2016, 127, 2618-2624. [CrossRef]

88. Kerasnoudis, A.; Pitarokoili, K.; Gold, R.; Yoon, M.S. Bochum ultrasound score allows distinction of chronic inflammatory from multifocal acquired demyelinating polyneuropathies. J. Neurol. Sci. 2015, 348, 211-215. [CrossRef]

89. Tanaka, K.; Ota, N.; Harada, Y.; Wada, I.; Suenaga, T. Normalization of sonographical multifocal nerve enlargements in a MADSAM patient following a good clinical response to intravenous immunoglobulin. Neuromuscul. Disord. NMD 2016, 26, 619-623. [CrossRef]

90. Grimm, A.; Rasenack, M.; Athanasopoulou, I.; Peters, N.; Fuhr, P. Long-term observations in asymmetric immune-mediated neuropathy with vagus hypertrophy using ultrasound of the nerves. J. Neurol. Sci. 2015, 356, 205-208. [CrossRef]

91. Mauermann, M.L. Paraproteinemic neuropathies. Continuum 2014, 20, 1307-1322. [CrossRef] [PubMed]

92. Nobile-Orazio, E.; Bianco, M.; Nozza, A. Advances in the Treatment of Paraproteinemic Neuropathy. Curr. Treat. Options Neurol. 2017, 19, 43. [CrossRef] [PubMed]

93. Athanasopoulou, I.M.; Rasenack, M.; Grimm, C.; Axer, H.; Sinnreich, M.; Décard, B.F.; Grimm, A. Ultrasound of the nerves-An appropriate addition to nerve conduction studies to differentiate paraproteinemic neuropathies. J. Neurol. Sci. 2016, 362, 188-195. [CrossRef] [PubMed]

94. Lucchetta, M.; Padua, L.; Granata, G.; Luigetti, M.; Campagnolo, M.; Dalla Torre, C.; Coraci, D.; Sabatelli, M.; Briani, C. Nerve ultrasound findings in neuropathy associated with anti-myelin-associated glycoprotein antibodies. Eur. J. Neurol. 2015, 22, 193-202. [CrossRef]

95. Vu, Q.D.; Cartwright, M.S. Neuromuscular ultrasound findings in distal acquired demyelinating symmetric variant of chronic inflammatory demyelinating polyneuropathy. Muscle Nerve 2017, 56, E44-E45. [CrossRef]

96. Lucchetta, M.; Pazzaglia, C.; Granata, G.; Briani, C.; Padua, L. Ultrasound evaluation of peripheral neuropathy in POEMS syndrome. Muscle Nerve 2011, 44, 868-872. [CrossRef]

97. Mitsuma, S.; Misawa, S.; Shibuya, K.; Isose, S.; Sekiguchi, Y.; Iwai, Y.; Beppu, M.; Watanabe, K.; Amino, H.; Kuwabara, S. Altered axonal excitability properties and nerve edema in POEMS syndrome. Clin. Neurophysiol. 2015, 126, 2014-2018. [CrossRef]

98. Vlam, L.; Van Der Pol, W.L.; Cats, E.A.; Straver, D.C.; Piepers, S.; Franssen, H.; van den Berg, L.H. Multifocal motor neuropathy: Diagnosis, pathogenesis and treatment strategies. Nat. Rev. Neurol. 2011, 8, 48-58. [CrossRef]

99. Harschnitz, O.; Jongbloed, B.A.; Franssen, H.; Straver, D.C.; van der Pol, W.L.; van den Berg, L.H. MMN: From immunological cross-talk to conduction block. J. Clin. Immunol. 2014, 34 (Suppl. 1), S112-S119. [CrossRef]

100. Harschnitz, O.; Van den Berg, L.H.; Johansen, L.E.; Jansen, M.D.; Kling, S.; Vieira de Sa, R.; Vlam, L.; van Rheenen, W.; Karst, H.; Wierenga, C.J.; et al. Autoantibody pathogenicity in a multifocal motor neuropathy induced pluripotent stem cell-derived model. Ann. Neurol. 2016, 80, 71-88. [CrossRef]

101. Beekman, R.; van den Berg, L.H.; Franssen, H.; Visser, L.H.; van Asseldonk, J.T.; Wokke, J.H. Ultrasonography shows extensive nerve enlargements in multifocal motor neuropathy. Neurology 2005, 65, 305-307. [CrossRef] [PubMed]

102. Grimm, A.; Décard, B.F.; Athanasopoulou, I.; Schweikert, K.; Sinnreich, M.; Axer, H. Nerve ultrasound for differentiation between amyotrophic lateral sclerosis and multifocal motor neuropathy. J. Neurol. 2015, 262, 870-880. [CrossRef] [PubMed] 
103. Loewenbruck, K.F.; Liesenberg, J.; Dittrich, M.; Schafer, J.; Patzner, B.; Trausch, B.; Machetanz, J.; Hermann, A.; Storch, A. Nerve ultrasound in the differentiation of multifocal motor neuropathy (MMN) and amyotrophic lateral sclerosis with predominant lower motor neuron disease (ALS/LMND). J. Neurol. 2016, 263, 35-44. [CrossRef] [PubMed]

104. Nodera, H.; Izumi, Y.; Takamatsu, N.; Kaji, R. Cervical root sonography to differentiate multifocal motor neuropathy from ALS. J. Med. Investig. 2016, 63, 104-107. [CrossRef] [PubMed]

105. Kerasnoudis, A.; Pitarokoili, K.; Behrendt, V.; Gold, R.; Yoon, M.S. Correlation of nerve ultrasound, electrophysiological, and clinical findings in post Guillain-Barre syndrome. J. Peripher. Nerv. Syst. 2013, 18, 232-240. [CrossRef]

106. Kerasnoudis, A.; Klasing, A.; Behrendt, V.; Gold, R.; Yoon, M.S. Intra- and internerve cross-sectional area variability: New ultrasound measures. Muscle Nerve 2013, 47, 146-147. [CrossRef]

107. de Leeuw, C.; Wijntjes, J.; Lassche, S.; van Alfen, N. Nerve ultrasound for distinguishing inflammatory neuropathy from amyotrophic lateral sclerosis: Not black and white. Muscle Nerve 2020, 61, E33-e37. [CrossRef]

108. Schreiber, S.; Vielhaber, S.; Schreiber, F.; Cartwright, M.S. Peripheral nerve imaging in amyotrophic lateral sclerosis. Clin. Neurophysiol. 2020, 131, 2315-2326. [CrossRef]

109. Wakerley, B.R.; Uncini, A.; Yuki, N. Guillain-Barré and Miller Fisher syndromes-new diagnostic classification. Nat. Rev. Neurol. 2014, 10, 537-544. [CrossRef]

110. De Sanctis, P.; Doneddu, P.E.; Vigano, L.; Selmi, C.; Nobile-Orazio, E. Guillain-Barre syndrome associated with SARS-CoV-2 infection. A systematic review. Eur. J. Neurol. 2020, 27, 2361-2370. [CrossRef]

111. Mohite, D.; Omole, J.A.; Bhatti, K.S.; Kaleru, T.; Khan, S. The Association of Anti-Ganglioside Antibodies in the Pathogenesis and Development of Zika-Associated Guillain-Barre Syndrome. Cureus 2020, 12, e8983. [CrossRef] [PubMed]

112. Grimm, A.; Decard, B.F.; Axer, H. Ultrasonography of the peripheral nervous system in the early stage of Guillain-Barre syndrome. J. Peripher. Nerv. Syst. 2014, 19, 234-241. [CrossRef] [PubMed]

113. Gallardo, E.; Sedano, M.J.; Orizaola, P.; Sanchez-Juan, P.; Gonzalez-Suarez, A.; Garcia, A.; Teran-Villagra, N.; Ruiz-Soto, M.; Alvaro, R.L.; Berciano, M.T.; et al. Spinal nerve involvement in early Guillain-Barre syndrome: A clinico-electrophysiological, ultrasonographic and pathological study. Clin. Neurophysiol. 2015, 126, 810-819. [CrossRef] [PubMed]

114. Razali, S.N.O.; Arumugam, T.; Yuki, N.; Rozalli, F.I.; Goh, K.J.; Shahrizaila, N. Serial peripheral nerve ultrasound in Guillain-Barre syndrome. Clin. Neurophysiol. 2016, 127, 1652-1656. [CrossRef] [PubMed]

115. Mori, A.; Nodera, H.; Takamatsu, N.; Maruyama-Saladini, K.; Osaki, Y.; Shimatani, Y.; Kaji, R. Sonographic evaluation of peripheral nerves in subtypes of Guillain-Barre syndrome. J. Neurol. Sci. 2016, 364, 154-159. [CrossRef]

116. Decard, B.F.; Fladt, J.; Axer, H.; Fischer, D.; Grimm, A. Nerve ultrasound in Miller Fisher variant of Guillain-Barre syndrome. Muscle Nerve 2015, 52, 1106-1110. [CrossRef]

117. Berciano, J.; Gallardo, E. Spinal nerve pathology in Guillain-Barre syndrome associated with COVID-19 infection. Muscle Nerve 2020, 62, E74-E75. [CrossRef]

118. Grimm, A.; Décard, B.F.; Schramm, A.; Pröbstel, A.K.; Rasenack, M.; Axer, H.; Fuhr, P. Ultrasound and electrophysiologic findings in patients with Guillain-Barré syndrome at disease onset and over a period of six months. Clin. Neurophysiol. 2016, 127, 1657-1663. [CrossRef]

119. Almeida, V.; Mariotti, P.; Veltri, S.; Erra, C.; Padua, L. Nerve ultrasound follow-up in a child with Guillain-Barre syndrome. Muscle Nerve 2012, 46, 270-275. [CrossRef]

120. Grimm, A.; Oertl, H.; Auffenberg, E.; Schubert, V.; Ruschil, C.; Axer, H.; Winter, N. Differentiation Between Guillain-Barré Syndrome and Acute-Onset Chronic Inflammatory Demyelinating Polyradiculoneuritis-a Prospective Follow-up Study Using Ultrasound and Neurophysiological Measurements. Neurotherapeutics 2019, 16, 838-847. [CrossRef]

121. Hobson-Webb, L.D.; Massey, J.M.; Juel, V.C. Nerve ultrasound in diabetic polyneuropathy: Correlation with clinical characteristics and electrodiagnostic testing. Muscle Nerve 2013, 47, 379-384. [CrossRef] [PubMed]

122. Pitarokoili, K.; Kerasnoudis, A.; Behrendt, V.; Labedi, A.; Ayzenberg, I.; Gold, R.; Yoon, M.S. Facing the diagnostic challenge: Nerve ultrasound in diabetic patients with neuropathic symptoms. Muscle Nerve 2016, 54, 18-24. [CrossRef] [PubMed]

123. Singh, K.; Gupta, K.; Kaur, S. High resolution ultrasonography of the tibial nerve in diabetic peripheral neuropathy. J. Ultrason 2017, 17, 246-252. [CrossRef] [PubMed]

124. Watanabe, T.; Ito, H.; Morita, A.; Uno, Y.; Nishimura, T.; Kawase, H.; Kato, Y.; Matsuoka, T.; Takeda, J.; Seishima, M. Sonographic evaluation of the median nerve in diabetic patients: Comparison with nerve conduction studies. J. Ultrasound Med. 2009, 28, 727-734. [CrossRef]

125. Breiner, A.; Qrimli, M.; Ebadi, H.; Alabdali, M.; Lovblom, L.E.; Abraham, A.; Albulahi, H.; Perkins, B.A.; Bril, V. Peripheral nerve high-resolution ultrasound in diabetes. Muscle Nerve 2017, 55, 171-178. [CrossRef]

126. Kang, S.; Kim, S.H.; Yang, S.N.; Yoon, J.S. Sonographic features of peripheral nerves at multiple sites in patients with diabetic polyneuropathy. J. Diabetes Complicat. 2016, 30, 518-523. [CrossRef]

127. Arumugam, T.; Razali, S.N.; Vethakkan, S.R.; Rozalli, F.I.; Shahrizaila, N. Relationship between ultrasonographic nerve morphology and severity of diabetic sensorimotor polyneuropathy. Eur. J. Neurol. 2016, 23, 354-360. [CrossRef]

128. Tawfik, E.A.; Walker, F.O.; Cartwright, M.S.; El-Hilaly, R.A. Diagnostic Ultrasound of the Vagus Nerve in Patients with Diabetes. J. Neuroimaging 2017, 27, 589-593. [CrossRef]

129. Kerasnoudis, A.; Woitalla, D.; Gold, R.; Pitarokoili, K.; Yoon, M.S. Sarcoid neuropathy: Correlation of nerve ultrasound, electrophysiological and clinical findings. J. Neurol. Sci. 2014, 347, 129-136. [CrossRef] 
130. Ito, T.; Kijima, M.; Watanabe, T.; Sakuta, M.; Nishiyama, K. Ultrasonography of the tibial nerve in vasculitic neuropathy. Muscle Nerve 2007, 35, 379-382. [CrossRef]

131. Grimm, A.; Decard, B.F.; Bischof, A.; Axer, H. Ultrasound of the peripheral nerves in systemic vasculitic neuropathies. J. Neurol. Sci. 2014, 347, 44-49. [CrossRef] [PubMed]

132. Üçeyler, N.; Schäfer, K.A.; Mackenrodt, D.; Sommer, C.; Müllges, W. High-Resolution Ultrasonography of the Superficial Peroneal Motor and Sural Sensory Nerves May Be a Non-invasive Approach to the Diagnosis of Vasculitic Neuropathy. Front. Neurol. 2016, 7, 48. [CrossRef] [PubMed]

133. Goedee, H.S.; van der Pol, W.L.; van Asseldonk, J.H.; Vrancken, A.; Notermans, N.C.; Visser, L.H.; van den Berg, L.H. Nerve sonography to detect peripheral nerve involvement in vasculitis syndromes. Neurol. Clin. Pract. 2016, 6, 293-303. [CrossRef] [PubMed]

134. Decard, B.F.; Grimm, A.; Andelova, M.; Deman, A.; Banderet, B.; Garcia, M.; Fuhr, P. Hepatitis-E virus associated neuralgic amyotrophy with sustained plexus brachialis swelling visualized by high-resolution ultrasound. J. Neurol. Sci. 2015, 351, 208-210. [CrossRef]

135. Dabir, A.; Pawar, G. Teaching NeuroImages: Lyme disease presenting as Bannwarth syndrome. Neurology 2018, 91, e1459-e1460. [CrossRef]

136. Grimm, A.; Décard, B.F.; Axer, H.; Fuhr, P. The Ultrasound pattern sum score-UPSS. A new method to differentiate acute and subacute neuropathies using ultrasound of the peripheral nerves. Clin. Neurophysiol. 2015, 126, 2216-2225. [CrossRef]

137. Lycan, T.W.; Hsu, F.C.; Ahn, C.S.; Thomas, A.; Walker, F.O.; Sangueza, O.P.; Shiozawa, Y.; Park, S.H.; Peters, C.M.; RomeroSandoval, E.A.; et al. Neuromuscular ultrasound for taxane peripheral neuropathy in breast cancer. Muscle Nerve 2020, 61, 587-594. [CrossRef]

138. Pitarokoili, K.; Hoffken, N.; Lonneker, N.; Fisse, A.L.; Trampe, N.; Gold, R.; Reinacher-Schick, A.; Yoon, M.S. Prospective Study of the Clinical, Electrophysiologic, and Sonographic Characteristics of Oxaliplatin-Induced Neuropathy. J. Neuroimaging 2019, 29, 133-139. [CrossRef]

139. Leadbetter, R.; Weatherall, M.; Pelosi, L. Nerve ultrasound as a diagnostic tool for sensory neuronopathy in spinocerebellar ataxia syndrome. Clin. Neurophysiol. 2019, 130, 568-572. [CrossRef]

140. Grisold, W.; Grisold, A.; Marosi, C.; Meng, S.; Briani, C. Neuropathies associated with lymphoma. Neurooncol. Pract. 2015, 2, 167-178. [CrossRef]

141. Campagnolo, M.; Cacciavillani, M.; Cavallaro, T.; Ferrari, S.; Gasparotti, R.; Zambello, R.; Briani, C. Neurolymphomatosis, a rare manifestation of peripheral nerve involvement in lymphomas: Suggestive features and diagnostic challenges. J. Peripher. Nerv. Syst. 2020, 25, 312-315. [CrossRef] [PubMed]

142. Ruzhansky, K.M.; Brannagan, T.H., 3rd. Neuromuscular complications of hematopoietic stem cell transplantation. Muscle Nerve 2015, 52, 480-487. [CrossRef] [PubMed]

143. Cocito, D.; Romagnolo, A.; Rosso, M.; Peci, E.; Lopiano, L.; Merola, A. CIDP-like neuropathies in graft versus host disease. J. Peripher. Nerv. Syst. 2015, 20, 1-6. [CrossRef] [PubMed]

144. Karam, C.; Mauermann, M.L.; Johnston, P.B.; Lahoria, R.; Engelstad, J.K.; Dyck, P.J. Immune-mediated neuropathies following stem cell transplantation. J. Neurol. Neurosurg. Psychiatry 2014, 85, 638-642. [CrossRef]

145. Kupper, H.; Kaiser, N.; Winter, N.; Kehrer, C.; Groeschel, S.; Bevot, A.; Nagele, T.; Krageloh-Mann, I.; Grimm, A. Enlargement of peripheral nerves in Krabbe disease: The diagnostic value of nerve ultrasound. Muscle Nerve 2020, 61, E24-E27. [CrossRef]

146. Grimm, A.; Schaffer, E.; Just, J.; Schols, L.; Kehrer, C.; Bevot, A.; Ziemann, U.; Krageloh-Mann, I. Thickening of the peripheral nerves in metachromatic leukodystrophy. J. Neurol. Sci. 2016, 368, 399-401. [CrossRef]

147. Rattay, T.W.; Just, J.; Röben, B.; Hengel, H.; Schüle, R.; Synofzik, M.; Söhn, A.S.; Winter, N.; Dammeier, N.; Schöls, L.; et al. Nerve ultrasound characterizes AMN polyneuropathy as inhomogeneous and focal hypertrophic. Orphanet J. Rare Dis. 2018, 13, 194. [CrossRef]

148. Mori, A.; Nodera, H.; Takamatsu, N.; Maruyama-Saladini, K.; Osaki, Y.; Shimatani, Y.; Oda, M.; Izumi, Y.; Kaji, R. Sonographic evaluation of cervical nerve roots in ALS and its clinical subtypes. J. Med. Investig. 2016, 63, 54-57. [CrossRef]

149. Grimm, A.; Rattay, T.W.; Winter, N.; Axer, H. Peripheral nerve ultrasound scoring systems: Benchmarking and comparative analysis. J. Neurol. 2017, 264, 243-253. [CrossRef]

150. Kerasnoudis, A.; Pitarokoili, K.; Behrendt, V.; Gold, R.; Yoon, M.S. Nerve ultrasound score in distinguishing chronic from acute inflammatory demyelinating polyneuropathy. Clin. Neurophysiol. 2014, 125, 635-641. [CrossRef]

151. Schreiber, S.; Dannhardt-Stieger, V.; Henkel, D.; Debska-Vielhaber, G.; Machts, J.; Abdulla, S.; Kropf, S.; Kollewe, K.; Petri, S.; Heinze, H.J.; et al. Quantifying disease progression in amyotrophic lateral sclerosis using peripheral nerve sonography. Muscle Nerve 2016, 54, 391-397. [CrossRef] [PubMed]

152. Schreiber, S.; Abdulla, S.; Debska-Vielhaber, G.; Machts, J.; Dannhardt-Stieger, V.; Feistner, H.; Oldag, A.; Goertler, M.; Petri, S.; Kollewe, K.; et al. Peripheral nerve ultrasound in amyotrophic lateral sclerosis phenotypes. Muscle Nerve 2015, 51, 669-675. [CrossRef] [PubMed]

153. Kerasnoudis, A.; Pitarokoili, K.; Haghikia, A.; Gold, R.; Yoon, M.S. Nerve ultrasound protocol in differentiating chronic immune-mediated neuropathies. Muscle Nerve 2016, 54, 864-871. [CrossRef] [PubMed]

154. Tawfik, E.A.; Cartwright, M.S.; Grimm, A.; Boon, A.J.; Kerasnoudis, A.; Preston, D.C.; Wilder-Smith, E.; Axer, H.; Hobson-Webb, L.D.; van Alfen, N.; et al. Guidelines for neuromuscular ultrasound training. Muscle Nerve 2019, 60, 361-366. [CrossRef] [PubMed] 
155. Walker, F.O.; Alter, K.E.; Boon, A.J.; Cartwright, M.S.; Flores, V.H.; Hobson-Webb, L.D.; Hunt, C.H.; Primack, S.J.; Shook, S.J. Qualifications for practitioners of neuromuscular ultrasound: Position statement of the American Association of Neuromuscular and Electrodiagnostic Medicine. Muscle Nerve 2010, 42, 442-444. [CrossRef]

156. Simon, N.G. Clinical and economic arguments to support a neuromuscular ultrasound service. Clin. Neurophysiol. Pract. 2019, 4, 168-169. [CrossRef] 